\title{
Atomic Layer Deposition of Molybdenum and Tungsten Oxide \\ Thin Films Using Heteroleptic Imido-Amidinato Precursors : \\ Process Development, Film Characterization, and Gas Sensing Properties
}

\author{
Mattinen, Miika
}

2018-12-11

Mattinen , M , Wree , J-L , Stegmann , N , Ciftyurek, E, El Achhab , M , King , P J , Mizohata , K, Räisänen , J , Schierbaum , K D , Devi , A , Ritala , M \& Leskelä , M 2018 , ' Atomic Layer Deposition of Molybdenum and Tungsten Oxide Thin Films Using Heteroleptic Imido-Amidinato Precursors : Process Development, Film Characterization, and Gas Sensing Properties ', Chemistry of Materials , vol. 30 , no. 23 , pp. 8690-8701 . https://doi.org/10.1021/acs.chemmat

http://hdl.handle.net/10138/306899

https://doi.org/10.1021/acs.chemmater.8b04129

acceptedVersion

Downloaded from Helda, University of Helsinki institutional repository.

This is an electronic reprint of the original article.

This reprint may differ from the original in pagination and typographic detail.

Please cite the original version. 


\title{
Atomic Layer Deposition of Molybdenum and Tungsten Oxide Thin Films Using Heteroleptic Imido-Amidinato Precursors: Process Development, Film Characterization, and Gas Sensing Properties
}

\author{
Miika Mattinen, ${ }^{* \dagger}$ Jan-Lucas Wree, ${ }^{\ddagger}$ Niklas Stegmann, ${ }^{\ddagger}$ Engin Ciftyurek, ${ }^{\ddagger}$ Mhamed \\ El Achhab, ${ }^{\ngtr}$ Peter J. King, ${ }^{\dagger}$ Kenichiro Mizohata, ${ }^{\S}$ Jyrki Räisänen, ${ }^{\S}$ Klaus D. \\ Schierbaum, ${ }^{*}$ Anjana Devi, ${ }^{\ddagger}$ Mikko Ritala, ${ }^{*}+$ Markku Leskelä ${ }^{\dagger}$
}

\author{
† Department of Chemistry, University of Helsinki, P.O. Box 55, ooo14, Finland \\ ‡ Inorganic Materials Chemistry, Faculty of Chemistry and Biochemistry, Ruhr-University Bochum, Universitätsstr. \\ 150, 44801 Bochum, Germany \\ $¥$ Material Science Department, Institute of Experimental Condensed Matter Physics, Heinrich Heine University \\ Düsseldorf, Universitätsstr. 1, 40225, Düsseldorf, Germany \\ $\S$ Division of Materials Physics, Department of Physics, University of Helsinki, P.O. Box 43, ooor4, Finland
}

\begin{abstract}
Heteroleptic bis(tert-butylimido)bis( $N, N$ '-diisopropylacetamidinato) compounds of molybdenum and tungsten are introduced as precursors for atomic layer deposition (ALD) of tungsten and molybdenum oxide thin films using ozone as the oxygen source. Both precursors have similar thermal properties, but exhibit different growth behavior. With the molybdenum precursor, high growth rates up to $2 \AA /$ cycle at $300{ }^{\circ} \mathrm{C}$ and extremely uniform films are obtained, although the surface reactions are not completely saturative. The corresponding tungsten precursor enables saturative film growth with a lower growth rate of $0.45 \AA$ A $/$ cycle at $300{ }^{\circ} \mathrm{C}$. Highly pure films of both metal oxides are deposited and their phase as well as stoichiometry can be tuned by changing the deposition conditions. The $\mathrm{WO}_{\mathrm{x}}$ films crystallize as $\gamma-\mathrm{WO}_{3}$ at $300{ }^{\circ} \mathrm{C}$ and above while the films deposited at lower temperatures are amorphous. Molybdenum oxide can be deposited as either amorphous $\left(\leq 250^{\circ} \mathrm{C}\right)$, crystalline suboxide $\left(275{ }^{\circ} \mathrm{C}\right)$, a mixture of suboxide and $\alpha-\mathrm{MoO}_{3}\left(300{ }^{\circ} \mathrm{C}\right)$, or pure $\alpha-\mathrm{MoO}_{3}$ films $\left(\geq 325^{\circ} \mathrm{C}\right) . \mathrm{MoO}_{\mathrm{x}}$ films are further characterized by synchrotron photoemission spectroscopy and temperaturedependent resistivity measurements. A suboxide $\mathrm{MoO}_{\mathrm{x}}$ film deposited at $275{ }^{\circ} \mathrm{C}$ is demonstrated to serve as an efficient hydrogen gas sensor at a low operating temperature of $120^{\circ} \mathrm{C}$.
\end{abstract}

\section{Introduction}

Molybdenum and tungsten have versatile yet rather similar oxide chemistry. Both elements form various compounds with different oxidation states, crystalline structures, and physical as well as chemical properties. ${ }^{1-6}$ The most important and stable oxides are the trioxides $\mathrm{MO}_{3}(\mathrm{M}$ $=\mathrm{Mo}, \mathrm{W})$, which exhibit several polymorphs and are wide band-gap semiconductors $\left(\mathrm{E}_{\mathrm{g}} \approx 2.5-3.5 \mathrm{eV}\right.$ ) with poor electrical conductivity in pristine form. In reducing conditions the trioxides easily form oxygen vacancies as well as crystalline suboxide phases, such as $\mathrm{Mo}_{4} \mathrm{O}_{11}\left(\mathrm{MoO}_{2.75}\right)$, $\mathrm{Mo}_{17} \mathrm{O}_{47} \quad\left(\approx \mathrm{MoO}_{2.76}\right), \quad \mathrm{Mo}_{8} \mathrm{O}_{23} \quad\left(\approx \mathrm{MoO}_{2.88}\right)$, and $\mathrm{Mo}_{9} \mathrm{O}_{26}$ $\left(\approx \mathrm{MoO}_{2.89}\right)$ for molybdenum, and $\mathrm{W}_{32} \mathrm{O}_{84}\left(\mathrm{WO}_{2.625}\right), \mathrm{W}_{18} \mathrm{O}_{49}$ $\left(\approx \mathrm{WO}_{2.72}\right), \mathrm{W}_{17} \mathrm{O}_{47}\left(\approx \mathrm{WO}_{2.76}\right)$, and $\mathrm{W}_{20} \mathrm{O}_{58}\left(\mathrm{WO}_{2.9}\right)$ for tungsten. ${ }^{4-7}$ The oxygen-deficient forms exhibit increased electrical conductivity and even metallic behavior. ${ }^{2,7-9}$ The dioxides $\mathrm{MO}_{2}$ are well-known metallic conductors. ${ }^{10}$

The similarities of molybdenum and tungsten oxides extend to the studied range of applications of $\mathrm{MO}_{3}$ and subox- ides, ${ }^{1-3}$ which include smart windows and other optical coatings, ${ }^{11}$ (photo)catalysis, ${ }^{12-14}$ gas sensors, ${ }^{15,16}$ nonvolatile memories, ${ }^{17-19}$ and lithium ion batteries. ${ }^{20}$ Obviously, as each crystalline phase has a different structure and properties, their performance in different applications vary accordingly. ${ }^{14,21-24}$

To highlight one promising application, $\mathrm{MoO}_{3}$ has recently been studied as a sensor for gases such as $\mathrm{H}_{2},{ }^{25-30} \mathrm{O}_{2},{ }^{31}$ $\mathrm{O}_{3},{ }^{31} \mathrm{NH}_{3},{ }^{30} \mathrm{NO}_{2},{ }^{26,31}$ and $\mathrm{SO}_{2}{ }^{32}$ Advantageously, $\mathrm{MoO}_{3}$ sensors may be operated at moderate temperatures, usually from 200 to $400{ }^{\circ} \mathrm{C} .{ }^{25,26,29,30}$ Hydrogen gas sensors, in particular, are rapidly gaining importance as hydrogen is being increasingly used as a clean energy source. $\mathrm{H}_{2}$ is a highly flammable yet colorless and odorless gas. Therefore, sensitive, reliable, and fast hydrogen sensors are needed to enable safe storage, transport, and use of hydrogen. ${ }^{33}$ Although various nanostructured forms of $\alpha-\mathrm{MoO}_{3}$ have shown respectable performance in $\mathrm{H}_{2}$ sensing, ${ }^{25,27,28}$ suboxide $\mathrm{MoO}_{\mathrm{x}}$ phases have not, to the best of our knowledge, been studied as $\mathrm{H}_{2}$ sensors. 
As outlined above, controlled deposition of uniform thin films and other nanostructures of molybdenum and tungsten oxides with desired phase and morphology is required to achieve optimal performance in different applications. As discussed in detail by de Castro et al. ${ }^{1}$ and Zheng et $\mathrm{al}^{3}{ }^{3}, \mathrm{MoO}_{\mathrm{x}}$ and $\mathrm{WO}_{\mathrm{x}}$ thin films and other nanostructures are typically deposited using techniques such as electrodeposition, hydro- or solvothermal synthesis, sol-gel process, chemical vapor deposition (CVD), and different physical vapor deposition (PVD) methods. However, using these methods, uniform coating on micro- and nanostructured substrates with high surface areas is rarely demonstrated and can be difficult or even impossible to accomplish. On the contrary, using atomic layer deposition (ALD), an advanced gas-phase thin film deposition method based on self-limiting surface reactions of alternately pulsed precursors, uniform coating of both large and complex substrates with accurately controlled film thickness and excellent reproducibility is easily achieved. ALD typically produces high-quality films at relatively low deposition temperatures and is also straightforward to scale up for industrial use. ${ }^{34-36}$

ALD is a chemical technique with several requirements for the precursors, ${ }^{34}$ including volatility, thermal stability, high reactivity, and lack of etching or dissolution reactions with the film or substrate. Thus, synthesizing, identifying, and evaluating suitable precursors are key steps in developing ALD processes. Due to the similar chemical properties of molybdenum and tungsten, analogous compounds have often been used as ALD precursors to deposit oxides of both metals, including [M(CO)6], ${ }^{37-39}$ $\left[\mathrm{M}\left(\mathrm{N}^{\mathrm{t} B u}\right)_{2}\left(\mathrm{NMe}_{2}\right)_{2}\right],{ }^{40-43}$ and $\left.\left[\mathrm{MO}_{2} \text { ( }{ }^{\mathrm{t} B u a m d}\right)_{2}\right](\mathrm{M}=\mathrm{Mo}$, $\mathrm{W}) .{ }^{44}$ However, some differences have been reported in the reactivity of the molybdenum and tungsten compounds under ALD conditions. For example, [W(NtBu $\left.)_{2}\left(\mathrm{NMe}_{2}\right)_{2}\right]$ reacts with $\mathrm{H}_{2} \mathrm{O},{ }^{43}$ whereas the corresponding Mo compound requires the use of more reactive $\mathrm{O}_{3}$ or $\mathrm{O}_{2}$ plasma. ${ }^{40,41}$ Additionally, some other metal precursors have been used to deposit either $\mathrm{MoO}_{\mathrm{x}}{ }^{45-49}$ or $\mathrm{WO}_{\mathrm{x}}{ }^{50-53}$ by ALD. Nevertheless, ALD of crystalline $\mathrm{MoO}_{\mathrm{x}}{ }^{48}$ or $\mathrm{WO}_{\mathrm{x}}{ }^{38,51}$ films without the use of plasma-enhancement or postdeposition annealing has been rarely achieved and only limited control over the different crystalline phases has been demonstrated. Therefore, it is evident that further efforts in precursor development are required to identify precursors that combine adequate thermal stability and reactivity with the ability to control the phase composition of the $\mathrm{MoO}_{\mathrm{x}}$ and $\mathrm{WO}_{\mathrm{x}}$ films.

In this report, we have studied all-nitrogen coordinated, heteroleptic bis(imido)-bis(amidinato) compounds $\left[\mathrm{M}\left(\mathrm{N}^{\mathrm{t} B u}\right)_{2}(\mathrm{dpamd})_{2}\right](\mathrm{M}=\mathrm{Mo}, \mathrm{W}$; dpamd = diisopropylacetamidinate) as ALD precursors. The compounds have promising thermal properties and have previously been used to deposit $\mathrm{WO}_{\mathrm{x}} \mathrm{N}_{\mathrm{y}}, \mathrm{WO}_{3}, \mathrm{WO}^{55} \mathrm{MN}_{\mathrm{x}},{ }^{56}$ and $\mathrm{MS}_{2}{ }^{57}$ films by CVD. The suitability of these precursors for ALD of $\mathrm{MoO}_{\mathrm{x}}$ and $\mathrm{WO}_{\mathrm{x}}(\mathrm{x} \approx 3)$ is shown using ozone as a reactant. Growth characteristics and film structure are examined in detail for both oxides. Clear differences between the metals are observed in terms of growth rates and crystallization behavior. Temperature-dependent resistivity and hydrogen gas sensing properties of $\mathrm{MoO}_{\mathrm{x}}$ films are further evaluated to highlight the high quality and performance of the deposited films.

\section{Experimental section}

Molybdenum and tungsten oxide films were deposited in a commercial, hot wall, cross-flow ASM F120 ALD reactor ${ }^{58}$ operating at approximately 5 mbar. Nitrogen $\left(\mathrm{N}_{2}, \mathrm{AGA}\right.$, 99.999\%) served both as carrier and purge gas. The films were mostly deposited on $5 \times 5 \mathrm{~cm}^{2}$ silicon (100) and soda lime glass substrates. The glass substrates were cleaned using successive ultrasonic baths of alkaline ultrasonic cleaning solution, tap water, ethanol, and de-ionized water. The silicon substrates were blown clean of particles using pressurized nitrogen. $4 \times 4 \mathrm{~mm}^{2} \mathrm{SiO}_{2}(500 \mathrm{~nm}) / \mathrm{Si} \mathrm{sub}-$ strates fixed to a $5 \times 5 \mathrm{~cm}^{2}$ Si carrier substrate with double-sided Kapton tape were used to prepare samples for the temperature-dependent resistivity and gas sensing measurements.

Bis(tert-butylimido)bis( $N, N^{\prime}$-diisopropylacetamidinato) compounds of molybdenum and tungsten were synthesized by salt methathesis. ${ }^{59}$ The compounds were evaporated from open glass boats inside the ALD reactor heated to $145{ }^{\circ} \mathrm{C}$ for $\left[\mathrm{Mo}\left(\mathrm{N}^{\mathrm{t} B u}\right)_{2}(\mathrm{dpamd})_{2}\right]$ and $155{ }^{\circ} \mathrm{C}$ for $\left.\left[\mathrm{W}\left(\mathrm{N}^{\mathrm{t} B u}\right)_{2} \text { (dpamd }\right)_{2}\right]$. The precursors were delivered to the substrates by $\mathrm{N}_{2}$ carrier gas flow and the pulsing was achieved by inert gas valving. ${ }^{58}$ Thermogravimetric analysis (TGA) of the precursors was performed using a Mettler Toledo STARe system equipped with a TGA850 thermobalance under atmospheric pressure of $\mathrm{N}_{2}$. The heating rate was $10{ }^{\circ} \mathrm{C} / \mathrm{min}$ and the sample size was approximately $10 \mathrm{mg}$.

Ozone $\left(\mathrm{O}_{3}\right)$ was produced from oxygen $\left(\mathrm{O}_{2}\right.$, AGA, 99.999\%) using an ozone generator (Wedeco Ozomatic Modular $4 \mathrm{HC}$ ) resulting in an $\mathrm{O}_{3}-\mathrm{O}_{2}$ mixture with a nominal $\mathrm{O}_{3}$ concentration of $100 \mathrm{~g} / \mathrm{Nm}^{3}$. The flow rate of the $\mathrm{O}_{3}$ $\mathrm{O}_{2}$ mixture was typically set to approximately $200 \mathrm{sccm}$ using a needle valve. Unless otherwise noted, the films were deposited at $300{ }^{\circ} \mathrm{C}$ using $1 \mathrm{~s}$ metal precursor and $5 \mathrm{~s}$ $\mathrm{O}_{3}$ pulses separated by $1 \mathrm{~s} \mathrm{~N}_{2}$ purges.

Further film deposition tests were done using de-ionized $\mathrm{H}_{2} \mathrm{O}, \mathrm{H}_{2} \mathrm{~S}$ (AGA, 99.5\%), and $\mathrm{NH}_{3}$ (AGA, 99.999\%) as the reactant. The reactants were pulsed by mechanical solenoid valves with flow rates set to approximately $10 \mathrm{sccm}$ for $\mathrm{H}_{2} \mathrm{~S}$ and $\mathrm{NH}_{3}$ during continuous flow using needle valves.

Film thicknesses were primarily measured by a Film Sense FS-1 multi-wavelength ellipsometer. Cauchy models were used to model the native silicon oxide and the film. For the roughest films, a roughness layer on the film surface was included in the model using effective medium approximation with $50 \%$ void content. Thickness mapping using the ellipsometer was performed for selected samples by measuring film thickness at points separated by $0.5 \mathrm{~cm}$ $(0.5 \mathrm{~cm}$ edge exclusion), resulting in 81 measurements over the $5 \times 5 \mathrm{~cm}^{2}$ silicon substrates. Energy-dispersive Xray spectroscopy (EDS, Oxford INCA connected to a Hitachi S-4800 SEM) and X-ray reflectivity (XRR, Rigaku Smartlab) were also used for some samples to confirm the ellipsometry thicknesses, as shown in the Supporting Information (Figure S1-S5). For EDS, the thicknesses were calculated from Mo and W L $\alpha$ k-ratios using GMRFilm software, ${ }^{60}$ 
assuming $\mathrm{MO}_{3}$ stoichiometry and bulk densities $\left(\mathrm{MoO}_{3} 4.7\right.$ $\left.\mathrm{g} / \mathrm{cm}^{3}, \mathrm{WO}_{3} 7.2 \mathrm{~g} / \mathrm{cm}^{3}\right) .{ }^{61}$ XRR was also used to determine film densities.

Film morphology was studied by scanning electron microscopy (SEM, Hitachi S-4800) and atomic force microscopy (AFM, Veeco Multimode V). Silicon probes with a tip radius of less than $10 \mathrm{~nm}$ (Bruker) were used for the tapping mode AFM imaging. The images were flattened to remove artefacts caused by sample tilt and scanner nonlinearity. Film roughness was calculated as a root mean square value $\left(R_{q}\right)$ from $2 \times 2 \mu m^{2}$ images.

Film crystallinity was examined by X-ray diffraction (XRD, Rigaku Smartlab) using $\mathrm{Cu} \mathrm{K \alpha}(\lambda=1.54 \AA$ ) x-ray beam and either grazing incidence (incident angle of $1^{\circ}$ ) or $\theta-2 \theta$ geometry. Raman spectroscopy was performed in backscattering geometry using a confocal Raman microscope (NT-MDT Ntegra) with a $100 \times$ objective and a 532 $\mathrm{nm}$ or $633 \mathrm{~nm}$ laser.

Film composition was analyzed by time-of-flight elastic recoil detection analysis (ToF-ERDA) using a $40 \mathrm{MeV}$ ${ }^{79} \mathrm{Br}^{7+}$ ion beam. The incident angle of the ion beam was $20^{\circ}$ with respect to the sample surface. The angle between the sample and the detector was also $20^{\circ}$, resulting in a scattering angle of $40^{\circ}$. Valence and core level X-ray induced photoelectron spectra were measured at Dortmund Electron Accelerator (DELTA) using synchrotron based Xray radiation of varied energy: $400 \mathrm{eV}$ for Mo $3 \mathrm{~d}$ and $\mathrm{C} 1 \mathrm{~s}$ and $630 \mathrm{eV}$ for 0 1s core levels, $65 \mathrm{eV}$ for valence band analysis, and 400,630, or $650 \mathrm{eV}$ for survey spectra. Two electron take-off angles of 0 or $60^{\circ}$ with respect to the sample normal were used. The $60^{\circ}$ take-off angle significantly increased surface sensitivity by probing less than half the depth of the $0^{\circ}$ measurement. $5 \mathrm{eV}$ pass energy and $0.5 \mathrm{eV}$ (survey) or $0.05 \mathrm{eV}$ (core and valence levels) step size were used. Sample surface was cleaned gently prior to measurements using low-energy $\mathrm{Ar}^{+}$ions at $0.5 \mathrm{kV}$ accelerating voltage for $15 \mathrm{~s}$. During the measurements, the chamber pressure was maintained at approximately $2 \times 10^{-10}$ mbar. The $\mathrm{C} 1 \mathrm{~s}$ peak at $284.5 \mathrm{eV}$ was used as an energy reference. The peak deconvolution was performed using Gaussian functions with Shirley background removal taking into account the spin orbit splitting and the ratios of the corresponding quantum states.

Temperature-dependent resistivity measurements were performed under atmospheric conditions using the van der Pauw (vdP) four-point geometry for $\mathrm{MoO}_{\mathrm{x}}$ samples deposited on $500 \mathrm{~nm} \mathrm{SiO} 2 / \mathrm{Si}$ substrates. A similar $\mathrm{MoO}_{\mathrm{x}} / 500 \mathrm{~nm}$ $\mathrm{SiO}_{2} / \mathrm{Si}$ structure with two silver (Ag) point contacts was used for hydrogen $\left(\mathrm{H}_{2}\right)$ sensing experiments. The gas atmosphere was controlled using mass flow controllers (MFCs, Bronkhorst Instruments) for hydrogen as well as for dry air that was used as the reference and balance gas. A Preama 5017 Digital Multimeter was used to measure current in a two-point configuration. In-house developed Labview software was used to control the flow rates of the testing and reference gases and to acquire the temperature and electrical current data. In all tests, the total flow was set to $50 \mathrm{sccm}$ by mixing $\mathrm{H}_{2}$ and dry air in defined proportions. $\mathrm{H}_{2}$ concentration was varied from 5000 to 35000 ppm ( 0.5 to 3.5 vol-\%). 15 minute pulses of $\mathrm{H}_{2}$ were mostly used with 15 minute pulses of dry air in between to allow the sensor surface to recover before the next measurement.

\section{Results and Discussion}

Bis(tert-butylimido)bis( $N, N^{\prime}$-diisopropylacetamidinato) compounds of both molybdenum and tungsten are solids that exhibit reasonably high and nearly identical volatility as shown by thermogravimetric analysis (TGA) in Figure 1. The residues of less than $3 \%$ at $500{ }^{\circ} \mathrm{C}$ suggest good thermal stability. The precursor temperatures needed to obtain sufficient vapor pressure for deposition experiments were estimated to be close to $150{ }^{\circ} \mathrm{C}$ for both compounds based on the previously developed empirical relation for our ALD reactor and TG instrument, ${ }^{62}$ which was further refined to $145{ }^{\circ} \mathrm{C}$ for $\left[\mathrm{Mo}\left(\mathrm{N}^{\mathrm{t}} \mathrm{Bu}\right)_{2}(\mathrm{dpamd})_{2}\right]$ and $155^{\circ} \mathrm{C}$ for $\left[\mathrm{W}\left(\mathrm{N}{ }^{\mathrm{B} u}\right)_{2}(\mathrm{dpamd})_{2}\right]$.

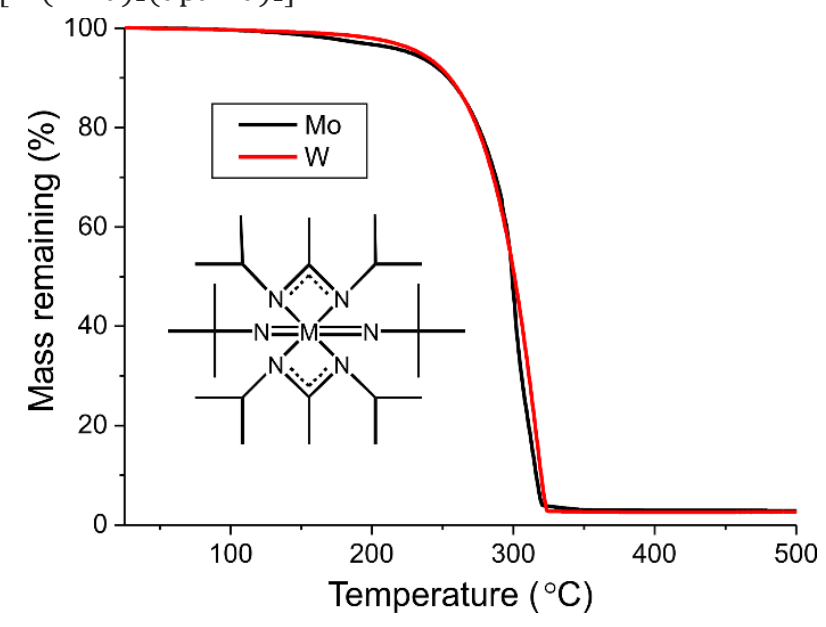

Figure 1. Thermogravimetric analysis of $\left[\mathrm{M}\left(\mathrm{N}^{\mathrm{t} B u}\right)_{2}(\mathrm{dpamd})_{2}\right]$ compounds, where $\mathrm{M}=$ Mo (black) and $\mathrm{W}$ (red), heated under atmospheric pressure of $\mathrm{N}_{2}$. The inset shows the schematic structure of the compounds.

We evaluated the reactivity of both compounds with different typical ALD reactants, including $\mathrm{H}_{2} \mathrm{O}$ and $\mathrm{O}_{3}, \mathrm{H}_{2} \mathrm{~S}$, and $\mathrm{NH}_{3}$ aiming to deposit oxides, sulfides, and nitrides, respectively. However, below the temperatures where the metal precursors were visually observed to decompose in the glass tubes of the ALD reactor, namely $300{ }^{\circ} \mathrm{C}$ for the Mo and $325{ }^{\circ} \mathrm{C}$ for the $\mathrm{W}$ precursor, films were only obtained using $\mathrm{O}_{3}$ as the reactant. This suggests that the hydrides $\left(\mathrm{H}_{2} \mathrm{O}, \mathrm{H}_{2} \mathrm{~S}\right.$, and $\left.\mathrm{NH}_{3}\right)$ are unable to protonate the ligands of the adsorbed precursors, whereas ozone is capable of combusting the ligands. Thus, we focused on the deposition of oxide films using $\mathrm{O}_{3}$. Other compounds of molybdenum and tungsten could likely be deposited using more reactive, perhaps plasma-activated reactants.

Initial deposition studies at $300{ }^{\circ} \mathrm{C}$ showed a high growth rate, around $1.5 \AA \AA$ Acycle, using $\left[\mathrm{Mo}\left(\mathrm{N}^{\mathrm{t} B u}\right)_{2}(\mathrm{dpamd})_{2}\right]$ and $\mathrm{O}_{3}$, compared to $0.45 \AA /$ cycle with $\left[\mathrm{W}\left(\mathrm{N}^{\mathrm{tBu}}\right)_{2}(\mathrm{dpamd})_{2}\right]$ and $\mathrm{O}_{3}$. However, saturation of the growth rate after a sufficient precursor dose is supplied, a unique characteristic of ALD, was not fully reached for molybdenum oxide when lengthening the 

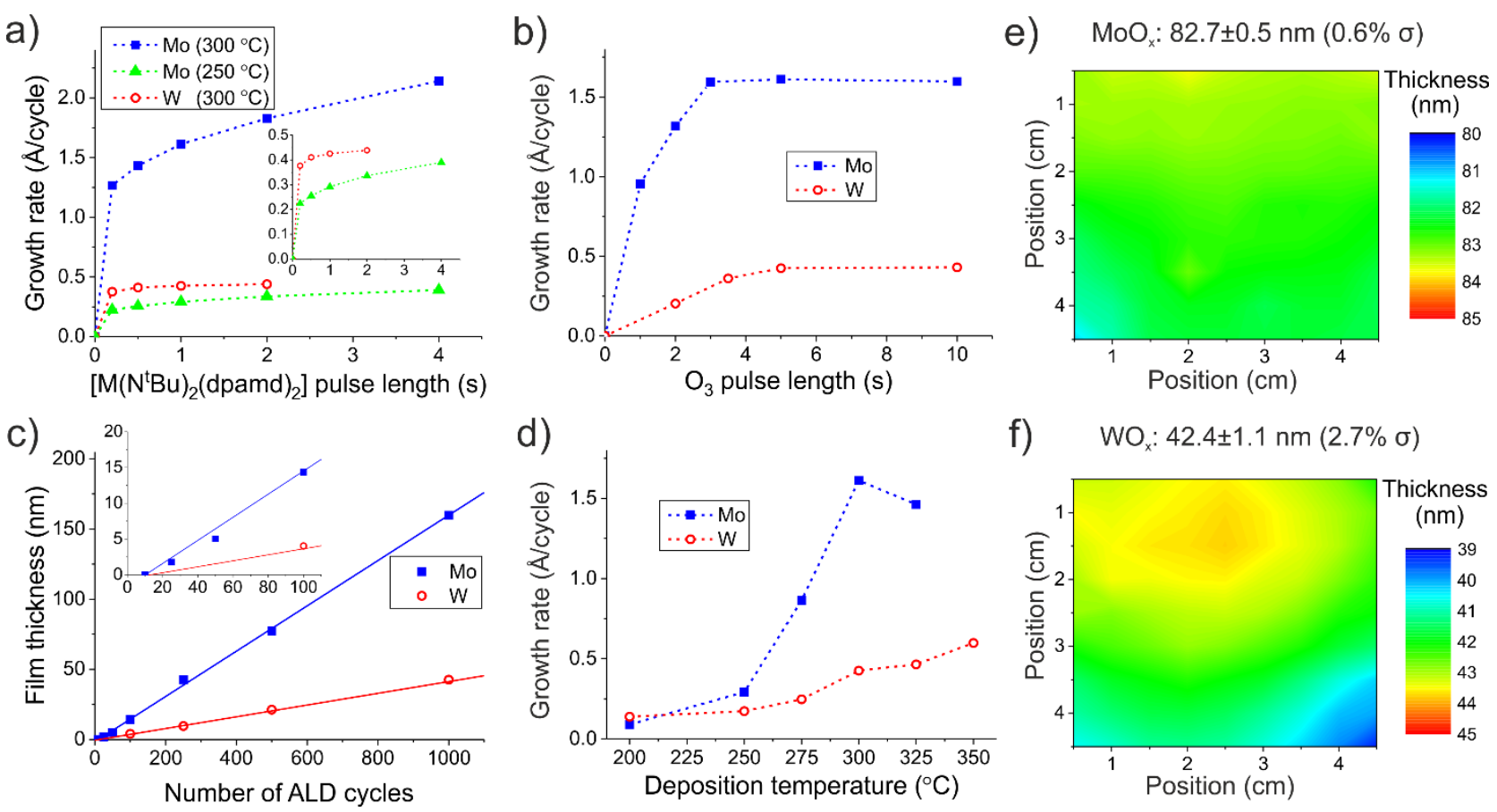

f) $\quad \mathrm{WO}_{\mathrm{x}}: 42.4 \pm 1.1 \mathrm{~nm}(2.7 \% \sigma)$

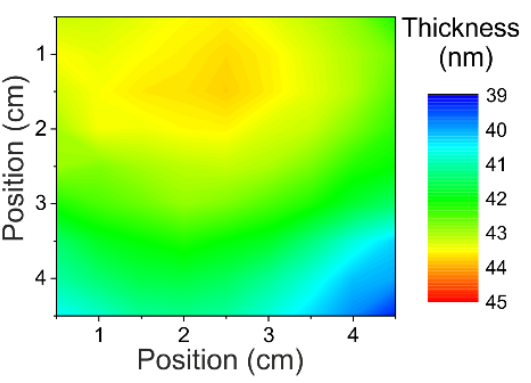

Figure 2. Growth rates of $\mathrm{MoO}_{\mathrm{x}}$ and $\mathrm{WO}_{\mathrm{x}}$ films versus a) $\left[\mathrm{M}(\mathrm{N} \mathrm{Bu})_{2}(\mathrm{dpamd})_{2}\right]$ (inset shows region below o.5 $\AA$ /cycle in more detail) and b) $\mathrm{O}_{3}$ pulse length. c) Film thickness as a function of ALD cycles with inset showing the first 100 cycles in more detail. d) Growth rate versus deposition temperature. Ellipsometry thickness maps of e) $\mathrm{MoO}_{\mathrm{x}}$ and f) $\mathrm{WO}_{\mathrm{x}}$ films with o.5 cm edge exclusion, where the precursor inlet and outlet are at the top and bottom of the figures, respectively. Unless otherwise noted, the films were deposited at $300{ }^{\circ} \mathrm{C}$ using 1000 cycles with $1 \mathrm{~s}\left[\mathrm{M}\left(\mathrm{N}^{\mathrm{t} B u}\right)_{2}(\mathrm{dpamd})_{2}\right]$ and $5 \mathrm{~s} \mathrm{O}_{3}$ pulses separated by $1 \mathrm{~s} \mathrm{~N}_{2}$ purges. The thicknesses were measured by ellipsometry, see Supporting Information for EDS and XRR results (Figure S1-S5). Solid lines represent linear fits to the data and dashed lines are meant to guide the eye.

$\left[\mathrm{Mo}\left(\mathrm{N}^{\mathrm{t} B u}\right)_{2}(\mathrm{dpamd})_{2}\right]$ pulse at $300{ }^{\circ} \mathrm{C}$ or even at $250{ }^{\circ} \mathrm{C}$ (Figure 2a), the latter being well below the decomposition temperature of the precursor as discussed below.

With $\mathrm{O}_{3}$ the growth rate saturated when pulses of at least $3 \mathrm{~s}$ were used (Figure 2b). In contrast, for tungsten oxide, saturation at $0.45 \AA$ /cycle was achieved with both precursors using $\left[\mathrm{W}\left(\mathrm{N}^{\mathrm{t} B u}\right)_{2}(\mathrm{dpamd})_{2}\right]$ and $\mathrm{O}_{3}$ pulses of at least 1 and 5 s, respectively (Figure $2 \mathrm{a}, \mathrm{b}$ ). All further depositions were done using $1 \mathrm{~s}\left[\mathrm{M}\left(\mathrm{N}^{\mathrm{t} B u}\right)_{2}(\mathrm{dpamd})_{2}\right]$ and $5 \mathrm{~s}$ $\mathrm{O}_{3}$ pulses separated by $1 \mathrm{~s}$ purges, unless otherwise noted.

The behavior of $\left[\mathrm{Mo}\left(\mathrm{N}^{\mathrm{tBu}}\right)_{2}(\mathrm{dpamd})_{2}\right]$ is similar to our earlier studies on $\left[\mathrm{MoO}_{2}\right.$ (thd) 2$]$ and $\mathrm{O}_{3}$, where the growth rate did not completely saturate with the $\left.\left[\mathrm{MoO}_{2} \text { (thd }\right)_{2}\right]$ pulse, even though no film was deposited when only $\left.\left[\mathrm{MoO}_{2} \text { (thd) }\right)_{2}\right]$ was pulsed. ${ }^{48}$ Here, the observed increase of the growth rate when lengthening the Mo precursor pulse at $300{ }^{\circ} \mathrm{C} \quad(\sim 0.2 \AA /$ cycle per additional $1 \mathrm{~s}$ of $\left[\mathrm{Mo}\left(\mathrm{N}^{\mathrm{t} B u}\right)_{2}(\mathrm{dpamd})_{2}\right]$ pulsing) greatly exceeded the decomposition observed when only $\left[\mathrm{Mo}\left(\mathrm{N}^{\mathrm{t} B u}\right)_{2}\right.$ (dpamd) 2$]$ was pulsed on silicon $(\sim 0.02 \AA /$ cycle for $1 \mathrm{~s}$ pulses $)$. This suggests precursor decomposition on the surface of the growing $\mathrm{MoO}_{\mathrm{x}}$ film as the main reason for the lack of saturation as opposed to decomposition on the starting $\mathrm{SiO}_{2}$ surface or in the gas phase. Furthermore, no film growth (decomposition) was observed when pulsing only $\left[\mathrm{Mo}\left(\mathrm{N}^{\mathrm{t} B u}\right)_{2}(\mathrm{dpamd})_{2}\right]$ on silicon at $250{ }^{\circ} \mathrm{C}$, yet the growth of $\mathrm{MoO}_{\mathrm{x}}$ films was not saturative at this temperature, either. Therefore, $\mathrm{MoO}_{\mathrm{x}}$ surface appears to have a catalytic effect in decomposition of the adsorbed $\left[\mathrm{Mo}\left(\mathrm{N}^{\mathrm{t} B u}\right)_{2}(\mathrm{dpamd})_{2}\right]$.
Both processes exhibited linear growth when the number of ALD cycles was varied, although the intersection of the fitted lines and the $\mathrm{x}$-axis at approximately 10 cycles suggests slight nucleation delay (Figure 2c). Notably, the linear growth behavior of $\mathrm{MoO}_{\mathrm{x}}$ is in contrast to the previous two ALD processes capable of depositing crystalline $\mathrm{MoO}_{\mathrm{x}}$ films, where initial slow growth of amorphous films was followed by faster growth after crystallization. ${ }^{40,48}$

Strong temperature dependence of the growth rate was evident for both processes, even more so for $\mathrm{MoO}_{\mathrm{x}}$ with the growth rate increasing from $0.1 \AA$ /cycle at $200^{\circ} \mathrm{C}$ to 1.6 $\AA$ /cycle at $300{ }^{\circ} \mathrm{C}$, whereas for $\mathrm{WO}_{\mathrm{x}}$ the growth rate increased rather linearly from $0.2 \AA$ /cycle at $200-250{ }^{\circ} \mathrm{C}$ to $0.6 \AA /$ cycle at $350{ }^{\circ} \mathrm{C}$ (Figure $2 \mathrm{~d}$ ). The glass source tubes inside the ALD reactor revealed the first visual signs of metal precursor decomposition at $300{ }^{\circ} \mathrm{C}$ for $\left[\mathrm{Mo}\left(\mathrm{N}^{\mathrm{t} B u}\right)_{2}\right.$ (dpamd)2], although film uniformity suffered only at $350{ }^{\circ} \mathrm{C}$. With $\left[\mathrm{W}\left(\mathrm{N}^{\mathrm{t} B u}\right)_{2}(\mathrm{dpamd})_{2}\right]$, decomposition was observed on the walls of the source tubes at $325{ }^{\circ} \mathrm{C}$ and above, but even the films deposited at $350{ }^{\circ} \mathrm{C}$ were uniform over the substrates. The increase in the growth rate with increasing deposition temperature when operating below the decomposition temperatures of the precursors is likely due to crystallization behavior of the films as discussed later, although changes in reaction mechanisms cannot be ruled out. 
a)

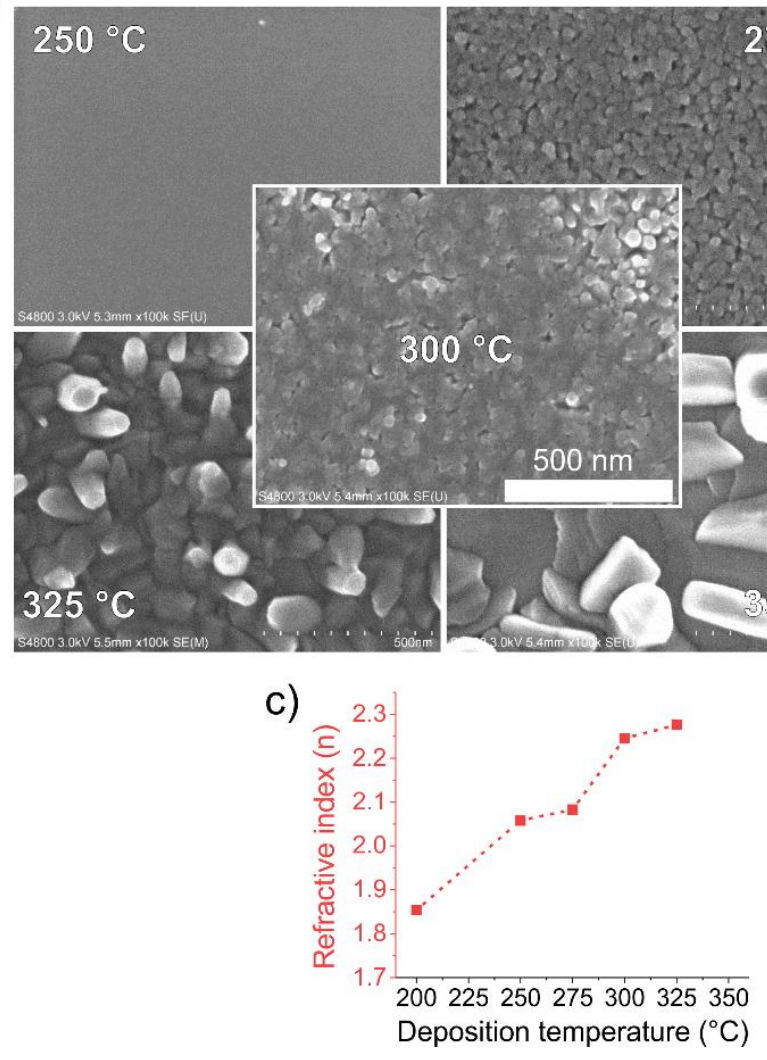

b)

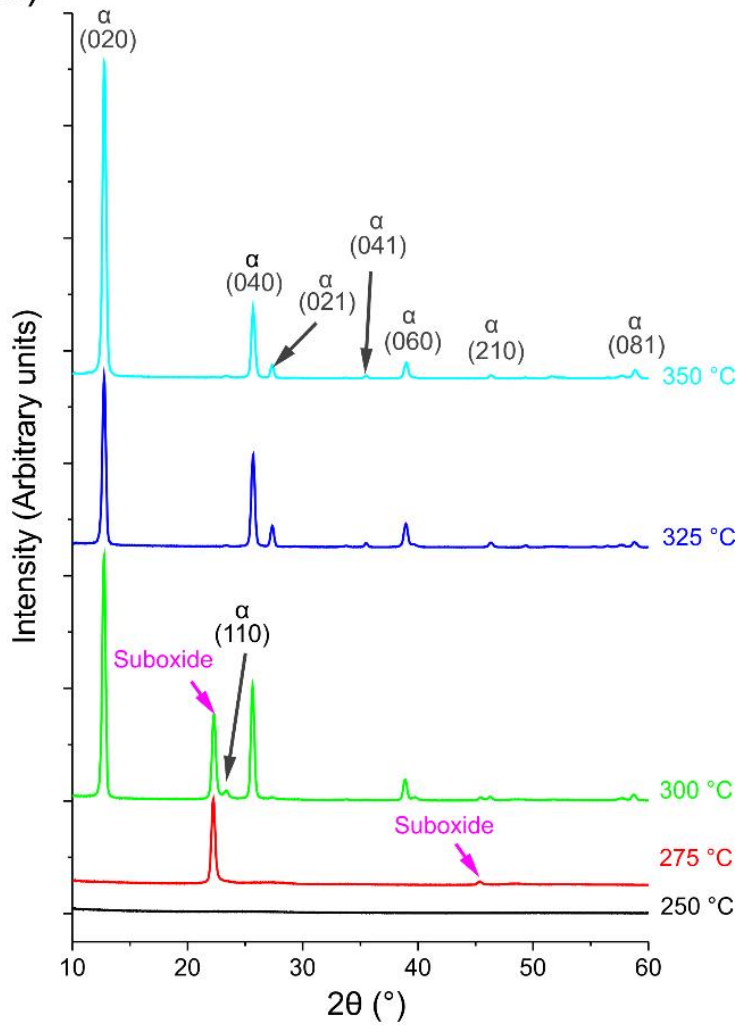

Figure 3. a) SEM images, b) grazing incidence X-ray diffractograms, and c) refractive indices (ellipsometry, at $630 \mathrm{~nm}$ ) of $\mathrm{MoO}_{\mathrm{x}}$ films deposited at different temperatures using 1000 cycles. $\alpha$ refers to $\alpha-\mathrm{MoO}_{3}(\mathrm{PDF}$ 005-0508).

Both processes yielded very uniform films at $300^{\circ} \mathrm{C}$. The uniformity of the $\mathrm{MoO}_{\mathrm{x}}$ films was remarkable - even though the growth rate did not completely saturate, the films had non-uniformity as low as $0.6 \%$ over the $5 \times 5$ $\mathrm{cm}^{2}$ substrates (Figure 2e).The research-scale cross-flow reactor used in this work typically results in higher nonuniformities compared to many other ALD reactor designs due to inlet effects caused by byproduct readsorption and impurities in the carrier gas, for example. ${ }^{34,36}$ For comparison, the $\mathrm{AlMe}_{3}+\mathrm{H}_{2} \mathrm{O}$ process, which is regarded as a nearideal, model ALD process, ${ }^{63}$ resulted in a non-uniformity of $0.8 \%$ in our ALD reactor at $300{ }^{\circ} \mathrm{C}$. The $\mathrm{WO}_{\mathrm{x}}$ films were also uniform with a $2.7 \%$ non-uniformity measured for an approximately $40 \mathrm{~nm}$ film deposited at $300{ }^{\circ} \mathrm{C}$ (Figure 2f).

Conformality, the unique ability of ALD to uniformly coat complex structures, was studied by depositing a $\mathrm{MoO}_{\mathrm{x}}$ film in a deep trench structure. Good, approximately $90 \%$ conformality was achieved up to an aspect ratio of 20 using the relatively short pulse and purge lengths selected for this experiment, although a change in film morphology as a function of the aspect ratio was observed (Figure S6 in Supporting Information).

The strong temperature-dependence of the $\mathrm{MoO}_{\mathrm{x}}$ film growth may be explained by changes in film crystallinity and morphology. The films deposited at $250{ }^{\circ} \mathrm{C}$ and below were very smooth, while the films deposited at $275^{\circ} \mathrm{C}$ and above were clearly rougher (Figure $3 \mathrm{a}$ ). Whereas the films deposited at 275 and $300^{\circ} \mathrm{C}$ still had a relatively compact and smooth-looking surface, those deposited at $325^{\circ} \mathrm{C}$ and especially $350{ }^{\circ} \mathrm{C}$ appeared very rough with tall rod-like grains present on the surface, in line with the matte-like visual appearance of the film deposited at $350{ }^{\circ} \mathrm{C}$.

The morphology was also correlated with the film crystallinity (Figure 3b): the smooth films deposited at $250{ }^{\circ} \mathrm{C}$ and below were amorphous, whereas at $275^{\circ} \mathrm{C}$ a strong $\mathrm{X}$ ray reflection emerged at $22.2^{\circ} 2 \theta$ accompanied by a weaker one at $45.4^{\circ}$, which corresponds to half of the $d$ spacing of the first reflection. These reflections are suggested to originate from a crystalline suboxide $\mathrm{MoO}_{\mathrm{x}}$ phase $(2.75 \leq \mathrm{x} \leq 2.89)$. Based on the peak positions, the most likely candidate is the orthorhombic $\gamma-\mathrm{Mo}_{4} \mathrm{O}_{11}$ (Powder Diffraction File, PDF 005-0337), although other suboxide phases also have reflections within $\pm 0.3^{\circ}$ of $22.2^{\circ}$, including monoclinic $\eta-\mathrm{Mo}_{4} \mathrm{O}_{11}$ (PDF 013-0142), $\mathrm{Mo}_{17} \mathrm{O}_{47}$ (PDF 013-0345), $\mathrm{Mo}_{5} \mathrm{O}_{14}$ (PDF 012-0517), $\mathrm{Mo}_{8} \mathrm{O}_{23}$ (PDF 0050339), and $\mathrm{Mog}_{9} \mathrm{O}_{26}$ in both triclinic (PDF 012-0753) and monoclinic (PDF 005-0441) forms. Thus, the suboxide phase could not be definitively identified by XRD. We were also unable to identify the suboxide phase by Raman spectroscopy (Figure S7 and Table S1 in Supporting Information).

In the samples made at $300{ }^{\circ} \mathrm{C}$, reflections of the stable orthorhombic $\alpha-\mathrm{MoO}_{3}$ (PDF 005-0508) appeared in addition to the suboxide reflections. The films deposited at 325 to $350{ }^{\circ} \mathrm{C}$ were phase-pure $\alpha-\mathrm{MoO}_{3} . \theta-2 \theta$ XRD measurements showed the $\alpha-\mathrm{MoO}_{3}$ to be preferentially oriented with the $(0 \mathrm{k} 0)$ planes parallel to the substrate (Figure S9 in Supporting Information). Previously, a three-phase mixture of a suboxide phase and both $\alpha$ and $\beta-\mathrm{MoO}_{3}$ phases was observed in ALD $\mathrm{MoO}_{\mathrm{x}}$ films deposited from 
$\left.\left[\mathrm{MoO}_{2} \text { (thd }\right)_{2}\right]$ and $\mathrm{O}_{3}$ at 225 to $260{ }^{\circ} \mathrm{C}$, whereas nearly phase-pure $\alpha-\mathrm{MoO}_{3}$ films was deposited at $300{ }^{\circ} \mathrm{C} .{ }^{48}$ Thus, the onset of crystallization was about $50{ }^{\circ} \mathrm{C}$ higher in the present process compared to the $\left.\left[\mathrm{MoO}_{2} \text { (thd }\right)_{2}\right]+\mathrm{O}_{3}$ process. In comparison, the PEALD process of Vos et al..$^{40}$ using $\left[\mathrm{Mo}\left(\mathrm{N}^{\mathrm{t} B u}\right)_{2}\left(\mathrm{NMe}_{2}\right)_{2}\right]$ and $\mathrm{O}_{2}$ plasma produced crystalline $\alpha-\mathrm{MoO}_{3}$ films at $300-350{ }^{\circ} \mathrm{C}$.

The refractive index (at $630 \mathrm{~nm}$ ) increased with increasing deposition temperature from 1.85 at $200{ }^{\circ} \mathrm{C}$ to 2.3 at $325^{\circ} \mathrm{C}$ (Figure 3c), which we attribute to densification and crystallization as well as changes in texture. Refractive indices of 1.8-2.2 at $\sim 630 \mathrm{~nm}$ have been reported for trioxide-like $\mathrm{MoO}_{\mathrm{x}}$ thin films. ${ }^{40,64}$ For reference, the refractive index of bulk $\alpha-\mathrm{MoO}_{3}$ single crystals at $589 \mathrm{~nm}$ has been shown to be strongly anisotropic, ranging from 1.88 to 2.54 along the a and c axes, respectively. ${ }^{65}$ XRR measurements showed that the amorphous films deposited at 250 ${ }^{\circ} \mathrm{C}$ had a rather low density of $3.6-3.7 \mathrm{~g} / \mathrm{cm}^{3}$ as compared to the $\mathrm{MoO}_{3}$ bulk density of $4.7 \mathrm{~g} / \mathrm{cm}^{3}{ }^{61}$ Unfortunately, high roughness prevented density measurements of our crystalline $\mathrm{MoO}_{\mathrm{x}}$ films by XRR.

Next, the effect of the $\mathrm{MoO}_{\mathrm{x}}$ film thickness on the morphology and crystallinity was examined by varying the number of ALD cycles at $300{ }^{\circ} \mathrm{C}$. The films started to roughen already after 50 cycles due to what appeared to be formation of crystallites on the surface (Figure 4a and Figure S9 in Supporting Information). Thereafter, the rootmean-square roughness remained nearly constant at 4 to 5 $\mathrm{nm}$ between 250 and 1000 cycles despite the four-fold increase in thickness. The morphology evolved from a surface pronouncedly exposing individual crystallites at 250 cycles to a more compact-looking surface at 1000 cycles. Grazing incidence X-ray diffraction (GIXRD) showed the first signs of the suboxide phase after 100 cycles, whereas $\alpha-\mathrm{MoO}_{3}$ started to form after 250 cycles. The relative amount of $\alpha-\mathrm{MoO}_{3}$ in comparison to the suboxide then increased with increasing number of cycles (GIXRD in Figure $4 \mathrm{~b}$ and $\theta-2 \theta$ XRD in Figure S10 in Supporting Information)

In addition to the deposition temperature and film thickness, the phase composition could be modified by changing the precursor pulse lengths. Increasing the $\left[\mathrm{Mo}\left(\mathrm{N}^{\mathrm{t} B u}\right)_{2}(\mathrm{dpamd})_{2}\right]$ pulse length at $300{ }^{\circ} \mathrm{C}$ increased the amount of the suboxide phase relative to $\alpha-\mathrm{MoO}_{3}$ and smoothened the film surface (Figure S11-S13 in Supporting Information), whereas $\mathrm{O}_{3}$ pulse length had the opposite effect (Figure S14-S16 in Supporting Information). In particular, nearly phase-pure $\alpha-\mathrm{MoO}_{3}$ was obtained using the longest, $10 \mathrm{~s} \mathrm{O}_{3}$ pulses. Effects of pulse times on film composition, crystallinity, and other properties are rarely examined, especially in the saturative ALD regime. Nevertheless, these effects are certainly not unique to this process, as similar observations have been made in ALD $\mathrm{MoO}_{x}{ }^{48} \mathrm{SnS},{ }^{66}$ and $\mathrm{TiN}^{67}$ processes, for example. a)

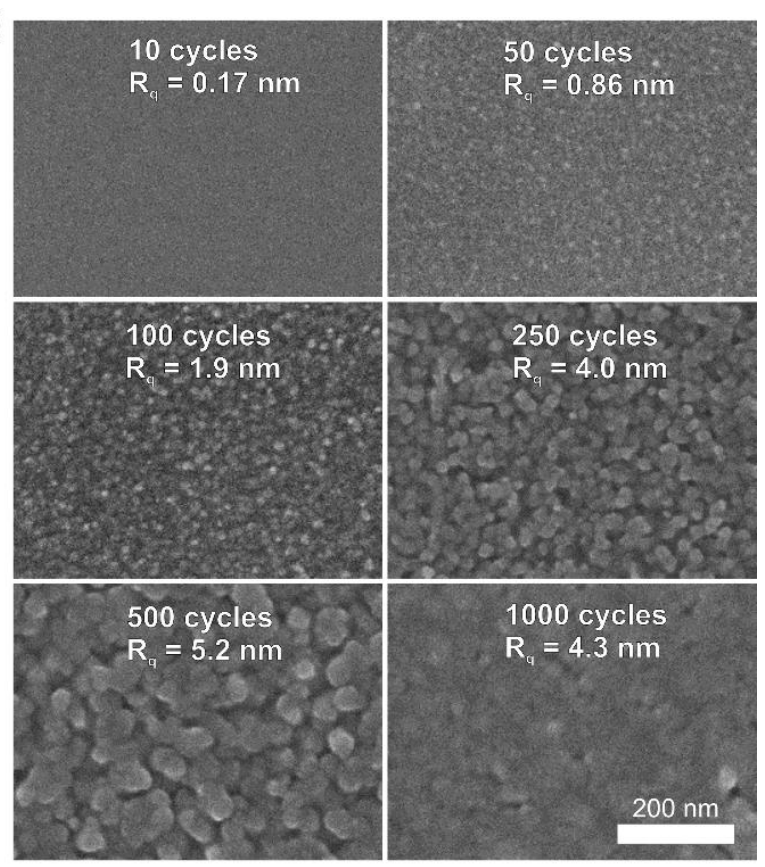

b)

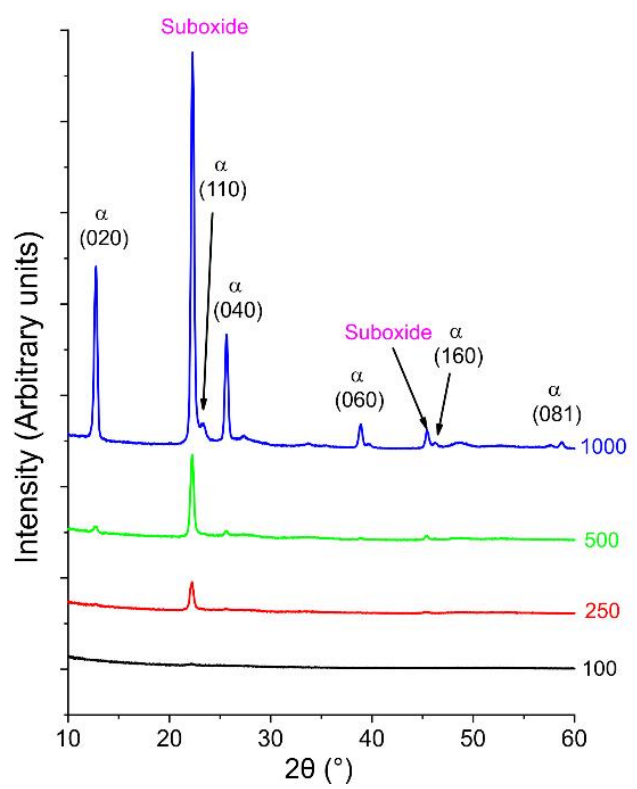

Figure 4. a) SEM images and roughness values $\left(R_{q}\right)$ determined by AFM as well as b) grazing incidence $\mathrm{X}$-ray diffractograms of $\mathrm{MoO}_{\mathrm{x}}$ films deposited at $300{ }^{\circ} \mathrm{C}$ with different number of ALD cycles. $\alpha$ refers to $\alpha-\mathrm{MoO}_{3}$ (PDF 005-0508).

The morphology of the $\mathrm{WO}_{\mathrm{x}}$ films was also strongly temperature-dependent. The films grown at $250{ }^{\circ} \mathrm{C}$ and below were smooth similar to the $\mathrm{MoO}_{\mathrm{x}}$ films, whereas individual crystallites started to form on the film surface at $275{ }^{\circ} \mathrm{C}$ and above (Figure 5a). Only the films deposited at 325 to $350{ }^{\circ} \mathrm{C}$ appeared to be fully crystalline, however. Thus, the crystallization of $\mathrm{WO}_{\mathrm{x}}$ seems to occur at slightly larger thicknesses and temperatures compared to $\mathrm{MoO}_{\mathrm{x}}$. 
a)

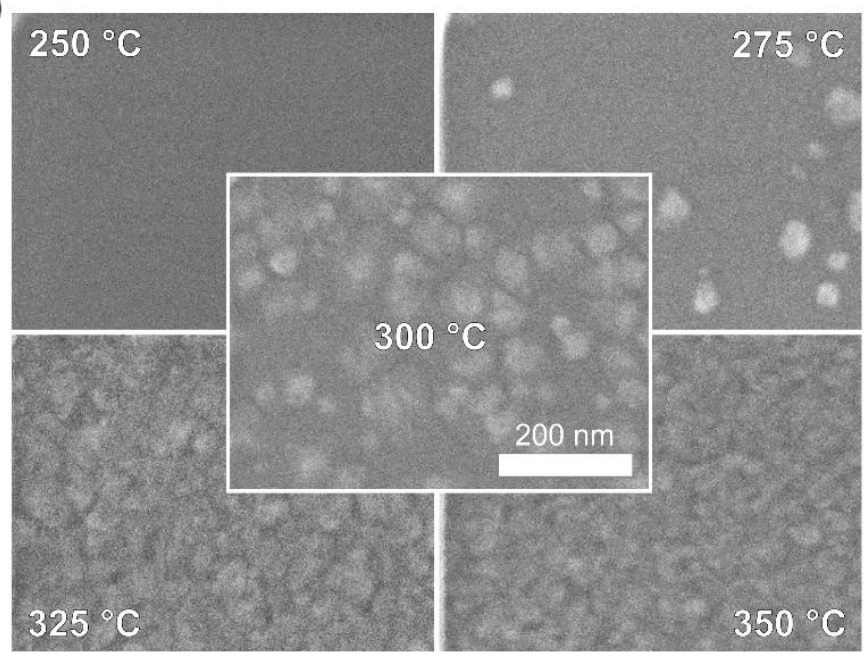

c)

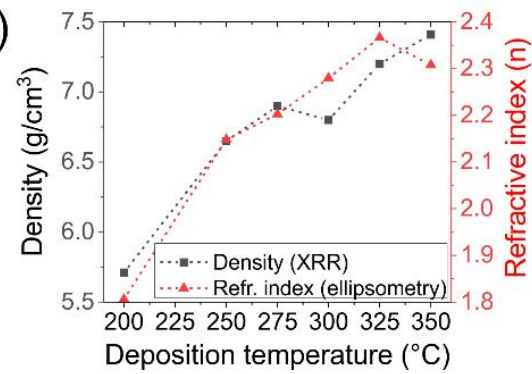

b)

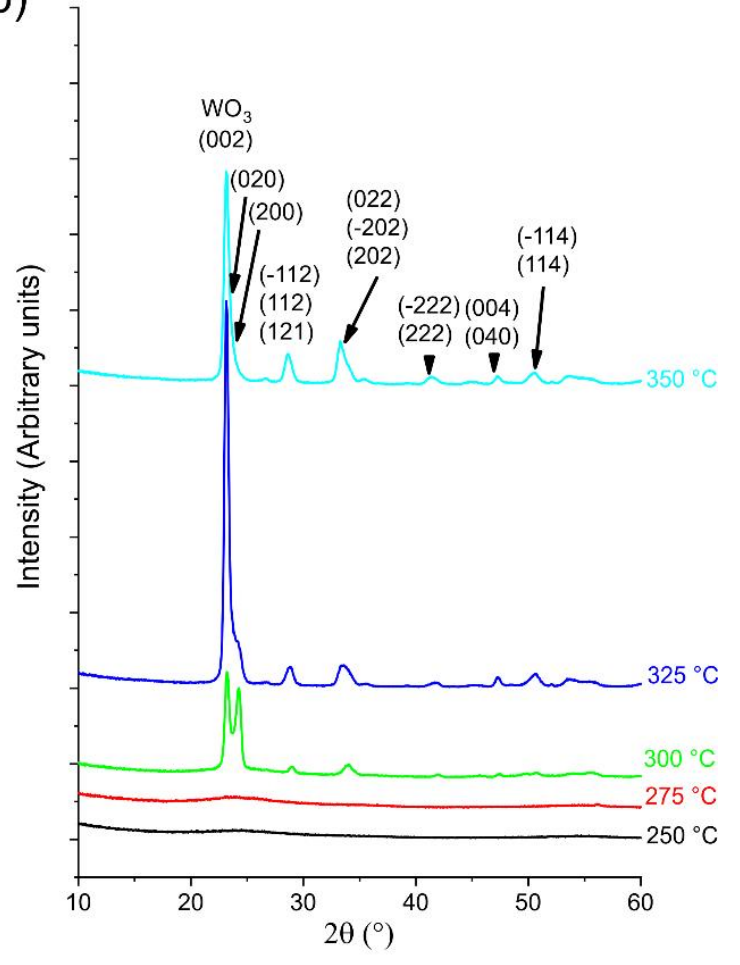

Figure 5. a) SEM images, b) grazing incidence X-ray diffractograms, and c) refractive indices (ellipsometry, at $630 \mathrm{~nm}$ ) and densities (XRR) of $\mathrm{WO}_{\mathrm{x}}$ films deposited at different temperatures using 1000 cycles.

Furthermore, the crystalline $\mathrm{WO}_{\mathrm{x}}$ films had a denser and smoother appearance compared to $\mathrm{MoO}_{\mathrm{x}}$. These interpretations are supported by GIXRD, which showed no signs of crystallinity at $250^{\circ} \mathrm{C}$, a very weak and broad peak at 275 ${ }^{\circ} \mathrm{C}$, and sharp peaks attributed to $\mathrm{WO}_{3}$ at $300{ }^{\circ} \mathrm{C}$ and above (Figure $5 \mathrm{~b}$ ). The films exhibited an increasing degree of preferred (002) orientation with increasing deposition temperature (Figure S17 in Supporting Information).

We indexed the reflections to the monoclinic $\gamma-\mathrm{WO}_{3}$ phase (PDF 043-1035), which is stable from 17 to $350{ }^{\circ} \mathrm{C}$ in bulk form, although other phases of $\mathrm{WO}_{3}$ including the triclinic $\delta-\mathrm{WO}_{3}$ (stable from -40 to $17{ }^{\circ} \mathrm{C}$, PDF 20-1323) and the orthorhombic $\beta-\mathrm{WO}_{3}$ (stable from 350 to $720^{\circ} \mathrm{C}$, PDF 020-1324) have similar structures and could not be definitively ruled out. ${ }^{68}$ Contrary to $\mathrm{MoO}_{\mathrm{x}}$, no suboxide $\mathrm{WO}_{\mathrm{x}}$ phases were seen in any of the films. Raman spectra of the $\mathrm{WO}_{\mathrm{x}}$ films deposited at $300{ }^{\circ} \mathrm{C}$ and above only revealed modes attributed to one of the $\mathrm{WO}_{3}$ phases (Figure S18 and Table S2 in Supporting Information).

Both the refractive indices (at $630 \mathrm{~nm}$ ) and densities of the $\mathrm{WO}_{\mathrm{x}}$ films increased with increasing deposition temperature, from 1.8 and $5.7 \mathrm{~g} / \mathrm{cm}^{3}$ at $200{ }^{\circ} \mathrm{C}$, respectively, up to 2.3 and $7.4 \mathrm{~g} / \mathrm{cm}^{3}$ at $350{ }^{\circ} \mathrm{C}$ (Figure $5 \mathrm{c}$ ). The refractive indices agree with reports on $\mathrm{WO}_{3}$ thin films, ${ }^{42,69}$ although even higher values from 2.28 to 2.70 along the $\mathrm{c}$ and aaxes, respectively, have been reported for bulk $\mathrm{WO}_{3}$ single crystals at the long-wavelength limit. ${ }^{70}$ The density of the films deposited at the highest temperatures is practically equivalent to the $\mathrm{WO}_{3}$ bulk density of $7.2 \mathrm{~g} / \mathrm{cm}^{3}{ }^{361}$
The thinnest $\mathrm{WO}_{\mathrm{x}}$ film deposited using 100 cycles at 300 ${ }^{\circ} \mathrm{C}$ (approximately $4 \mathrm{~nm}$ ) was smooth (Figure 6a) and amorphous (Figure 6b and Figure S19 in Supporting Information). A few small crystallites were visible on the surface after 250 cycles, but XRD detected crystallinity only after 500 cycles. After 1000 cycles at $300{ }^{\circ} \mathrm{C}$ the surface still had some smooth, likely amorphous areas.

The crystallinity of the $\mathrm{WO}_{\mathrm{x}}$ films was also correlated to the precursor pulse lengths used, as was observed for the $\mathrm{MoO}_{\mathrm{x}}$ films. The $\left[\mathrm{W}\left(\mathrm{N}^{\mathrm{t}} \mathrm{Bu}\right)_{2}(\mathrm{dpamd})_{2}\right]$ pulse length yielding the highest crystallinity and density at $300{ }^{\circ} \mathrm{C}$ was $0.5 \mathrm{~s}$, below the length needed for the saturation (Figure S20S22 in Supporting Information). On the other hand, lengthening the $\mathrm{O}_{3}$ pulse length increased the crystallinity, density, refractive index, and the degree of the preferred (002) orientation (Figure S23-S25 in Supporting Information).

Both the $\mathrm{MoO}_{\mathrm{x}}$ (Table 1) and $\mathrm{WO}_{\mathrm{x}}$ (Table 2) films were relatively close to the $\mathrm{MO}_{3}$ stoichiometry with low impurity contents according to ToF-ERDA. For the $\mathrm{MoO}_{\mathrm{x}}$ films deposited at $275^{\circ} \mathrm{C}$ the $\mathrm{O} /$ Mo stoichiometry of 2.80 was in line with the film being at least partly crystalline suboxide $(2.75 \leq \mathrm{x} \leq 2.89)$, whereas the $\alpha-\mathrm{MoO}_{3}$ film deposited at $325^{\circ} \mathrm{C}$ had an excess of oxygen (O/Mo 3.19). The $\mathrm{C}$ and $\mathrm{N}$ levels, likely originating from the precursor ligands, were low and generally decreased with increasing deposition temperature. The somewhat higher hydrogen content in the $\mathrm{MoO}_{\mathrm{x}}$ films (1.4-2.7 at.\%) showed little

Table 1. Composition of $\mathrm{MoO}_{\mathrm{x}}$ films deposited using 1000 cycles as determined by ToF-ERDA. 


\begin{tabular}{lllllll}
\hline $\mathrm{T}\left({ }^{\circ} \mathrm{C}\right)$ & Mo (at.\%) & O (at.\%) & O / Mo & C (at.\%) & N (at.\%) & H (at.\%) \\
\hline 275 & $25.3 \pm 0.3$ & $70.8 \pm 0.9$ & $2.80 \pm 0.05$ & $0.62 \pm 0.09$ & $1.27 \pm 0.12$ & $2.0 \pm 0.4$ \\
\hline 300 & $23.5 \pm 0.2$ & $72.6 \pm 0.6$ & $3.09 \pm 0.04$ & $0.19 \pm 0.03$ & $1.03 \pm 0.08$ & $2.7 \pm 1.2$ \\
\hline 325 & $23.4 \pm 0.3$ & $74.6 \pm 0.8$ & $3.19 \pm 0.05$ & $0.33 \pm 0.06$ & $0.36 \pm 0.05$ & $1.4 \pm 0.3$ \\
\hline
\end{tabular}

Table 2. Composition of $\mathrm{WO}_{\mathrm{x}}$ films deposited using 1000 cycles as determined by ToF-ERDA.

\begin{tabular}{lllllll}
\hline $\mathrm{T}\left({ }^{\circ} \mathrm{C}\right)$ & $\mathrm{W}($ at.\%) & $\mathrm{O}($ at.\%) & $\mathrm{O} / \mathrm{W}$ & $\mathrm{C}($ at.\%) & $\mathrm{N}($ at.\%) & H (at.\%) \\
\hline 300 & $25.3 \pm 0.3$ & $73.4 \pm 1.9$ & $2.90 \pm 0.08$ & $0.38 \pm 0.14$ & $0.48 \pm 0.13$ & $0.39 \pm 0.21$ \\
\hline 350 & $25.0 \pm 0.2$ & $73.7 \pm 1.3$ & $2.95 \pm 0.06$ & $0.40 \pm 0.09$ & $0.32 \pm 0.08$ & $0.61 \pm 0.23$ \\
\hline
\end{tabular}

a)

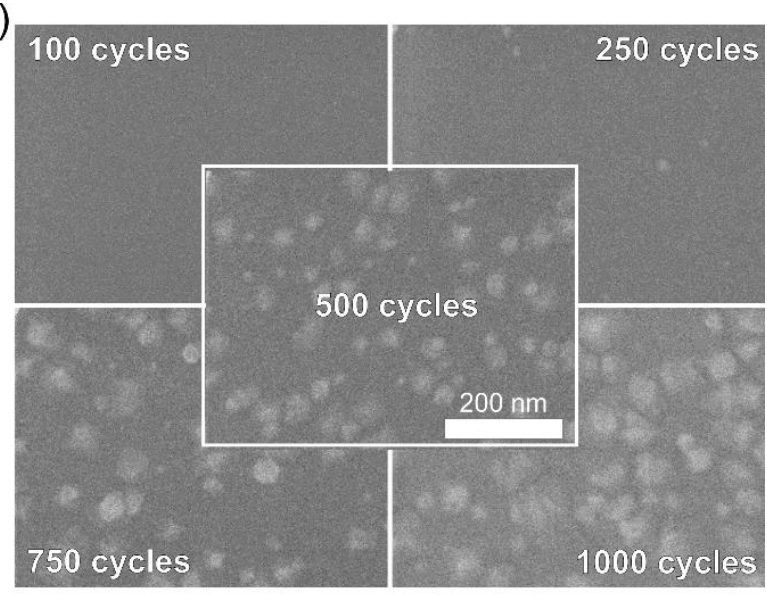

b)

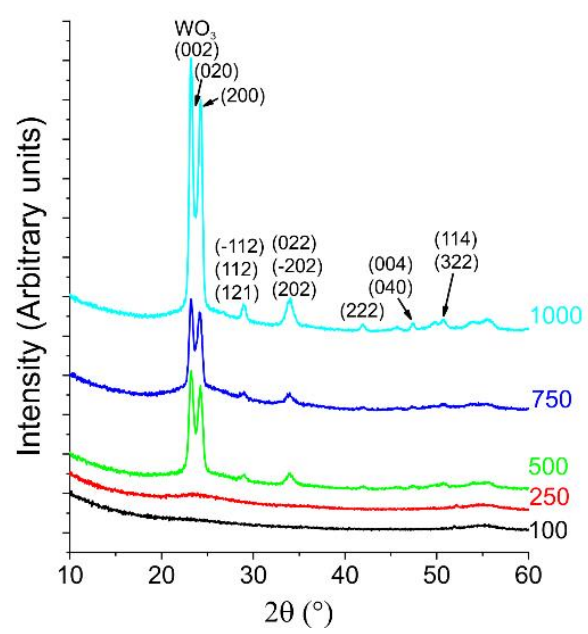

Figure 6. a) SEM images and b) grazing incidence X-ray diffractograms of $\mathrm{WO}_{\mathrm{x}}$ films deposited with different number of ALD cycles at $300^{\circ} \mathrm{C}$.

correlation with carbon and nitrogen and is thus attributed to hydroxyl $\left(\mathrm{OH}^{-}\right)$groups, which would also explain some of the excess oxygen in the films. The $\mathrm{WO}_{\mathrm{x}}$ films deposited at both 300 and $350{ }^{\circ} \mathrm{C}$ were close to the $\mathrm{WO}_{3}$ stoichiometry (O/W 2.9-2.95) with very low impurity contents; only about 1.3 at.\% of $\mathrm{C}, \mathrm{N}$, and $\mathrm{H}$ combined. The impurity contents were lower or on similar level compared to the reported ALD $\mathrm{MoO}_{\mathrm{x}}{ }^{40,48}$ and $\mathrm{WO}_{\mathrm{x}}{ }^{38,42}$ films.

In order to gain further insight into the structure and composition of the scarcely studied suboxide $\mathrm{MoO}_{\mathrm{x}}$ films, we used synchrotron photoemission spectroscopy to characterize a $50 \mathrm{~nm}$ molybdenum oxide film deposited at 275 ${ }^{\circ} \mathrm{C}$. Measurements were done after gentle $\mathrm{Ar}^{+}$sputtering using two take-off angles, 0 and $60^{\circ}$ with respect to the surface normal, the latter resulting in increased surface sensitivity. Survey scans detected only Mo, O, and C, the last one being a surface contaminant (Figure S26 in Supporting Information). The broad Mo $3 \mathrm{~d}$ doublet at $0^{\circ}$ takeoff angle was deconvoluted to three chemical states (Figure $7 \mathrm{a}$ ): $\mathrm{Mo}^{6+}, \mathrm{Mo}^{5+}$, and $\mathrm{Mo}^{4+}$ with $\mathrm{Mo} 3 \mathrm{~d}_{5 / 2}$ binding energies (and relative amounts) of $233.0 \mathrm{eV}(28 \%), 231.6 \mathrm{eV}$ (51\%), and $230.2 \mathrm{eV}(21 \%)$, respectively (Table S3 in Supporting Information). $32,71,72$ Compared to the $\mathrm{MoO}_{2.8}$ composition determined by ToF-ERDA as an average through the film thickness, photoemission spectroscopy yielded a more oxygen-deficient composition: $\mathrm{MoO}_{2.6}$ and $\mathrm{MoO}_{2.4}$ at $0^{\circ}$ and $60^{\circ}$ take-off angles, respectively, which suggests that the oxidation state of molybdenum and the $0 /$ Mo ratio were lower on the film surface than in the film bulk. The surface composition may have changed while cooling the film in vacuum after the film deposition or during storage in air.

Five main chemical states were identified in the $01 \mathrm{~s}$ spectra (Figure 7a) at $534.4 \mathrm{eV}$ (adsorbed $\mathrm{H}_{2} \mathrm{O}$ ), $533.7 \mathrm{eV}$ (surface $\left.\mathrm{OH}^{-}\right), 532.8 \mathrm{eV}\left(\mathrm{O}^{2-}\right.$ bonded with $\left.\mathrm{Mo}^{4+}\right), 531.5 \mathrm{eV}$ $\left(\mathrm{O}^{2-}\right.$ bonded with $\left.\mathrm{Mo}^{5+}\right)$, and $530.6 \mathrm{eV}\left(\mathrm{O}^{2-}\right.$ bonded with $\mathrm{Mo}^{6+}$ ). The valence band spectra show convoluted Mo 4d and $5 \mathrm{~s}$ as well as $02 \mathrm{p}$ features between 5 and $15 \mathrm{eV}$ and 0 $2 \mathrm{~s}$ levels near $23 \mathrm{eV}$ (Figure $7 \mathrm{~b}$ ). The defect states located at approximately $3 \mathrm{eV}$ below the Fermi level were attributed to oxygen vacancies of the $\mathrm{MoO}_{\mathrm{x}}$ film, which are more pronounced on the surface ( $60^{\circ}$ take-off angle).

The valence band maximum was located at $1.0 \mathrm{eV}$ below the Fermi level. We estimated the work function of the film by extrapolating the linear part of the secondary electron cut-off to zero and deducting this from the excitation photon energy of $65 \mathrm{eV}$ (not shown). This procedure yielded values of 6.0 and $7.0 \mathrm{eV}$ at 0 and $60^{\circ}$ take-off angles, respectively. The higher work function at the $60^{\circ}$ take-off angle is attributed to surface contamination and hydroxyl groups, whereas the value of $6.0 \mathrm{eV}$ obtained at $0^{\circ}$ matches those reported for non-stoichiometric $\mathrm{MoO}_{\mathrm{x} .}{ }^{73-75}$

Next, to explore the suitability of $\mathrm{MoO}_{\mathrm{x}}$ films for gas sensing, we performed temperature-dependent resistivity measurements in air on $50 \mathrm{~nm} \mathrm{MoO}_{\mathrm{x}}$ films deposited at 
275 and $300{ }^{\circ} \mathrm{C}$, which consisted of the suboxide and a mixture of the suboxide and $\alpha-\mathrm{MoO}_{3}$ phases, respectively (Figure S27 in Supporting Information). Both films had a resistivity of approximately $80 \Omega \mathrm{cm}$ at $40{ }^{\circ} \mathrm{C}$ (Figure 8). The resistivity first increased up to $76^{\circ} \mathrm{C}$, likely due to desorption of $\mathrm{H}_{2} \mathrm{O}$, and then decreased at higher temperatures as expected for semiconductors. The film deposited at $300{ }^{\circ} \mathrm{C}$ had a higher resistivity between 115 and $189{ }^{\circ} \mathrm{C}$ than the film deposited at $275{ }^{\circ} \mathrm{C}$ probably due to the greater oxygen deficiency of the latter.

a)

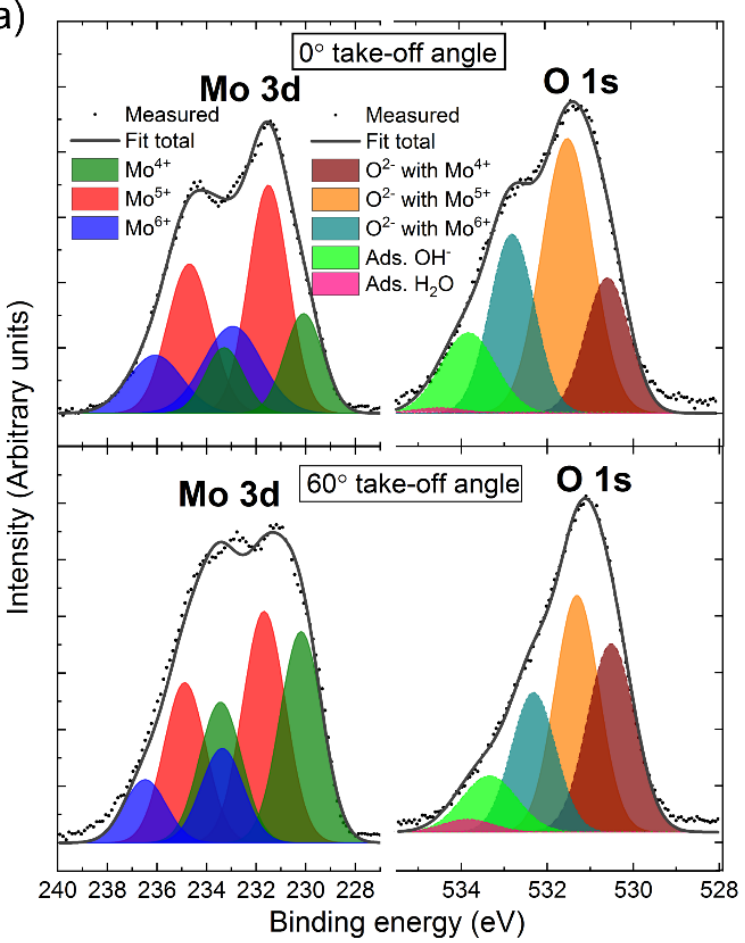

b)

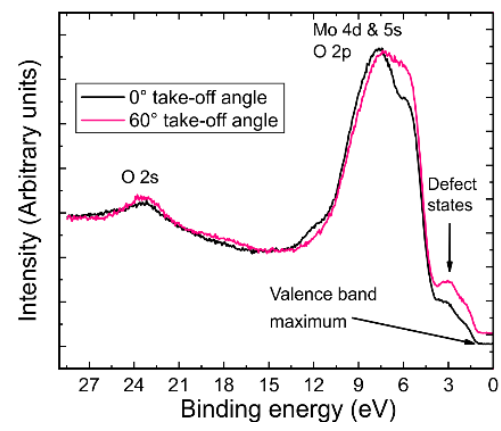

Figure 7. a) High resolution $\mathrm{Mo} 3 \mathrm{~d}$ and $\mathrm{O}$ 1s $\mathrm{X}$-ray photoemission spectra and $b$ ) valence band region of a $50 \mathrm{~nm}$ $\mathrm{MoO}_{\mathrm{x}}$ films deposited at $275^{\circ} \mathrm{C}$ measured at o and $60^{\circ}$ takeoff angles.

Above $200{ }^{\circ} \mathrm{C}$ the difference between the samples decreased, likely due to annealing of surface defects. Both films ended up having a resistivity of $6-7 \Omega \mathrm{cm}$ at $330^{\circ} \mathrm{C}$. Identical results were obtained on cooling the film and repeating the measurements, which shows that no irreversible changes in film structure occurred up to $330^{\circ} \mathrm{C}$.

The measured resistivity values are relatively low compared to stoichiometric $\mathrm{MoO}_{3}$, which has a resistivity above $10^{9} \Omega \mathrm{cm}$ at room temperature. ${ }^{76,77}$ Various subox- ides have been reported to have much lower resistivities compared to $\mathrm{MoO}_{3}$, ranging from $100 \Omega \mathrm{cm}$ for $\mathrm{Mog}_{9} \mathrm{O}_{26}$ to as low as $10^{-4} \Omega \mathrm{cm}$ for $\gamma-\mathrm{Mo}_{4} \mathrm{O}_{11}{ }^{8,9}$ Additionally, easily forming oxygen vacancies are known to greatly enhance the conductivity of $\mathrm{MoO}_{3 .}{ }^{1}$

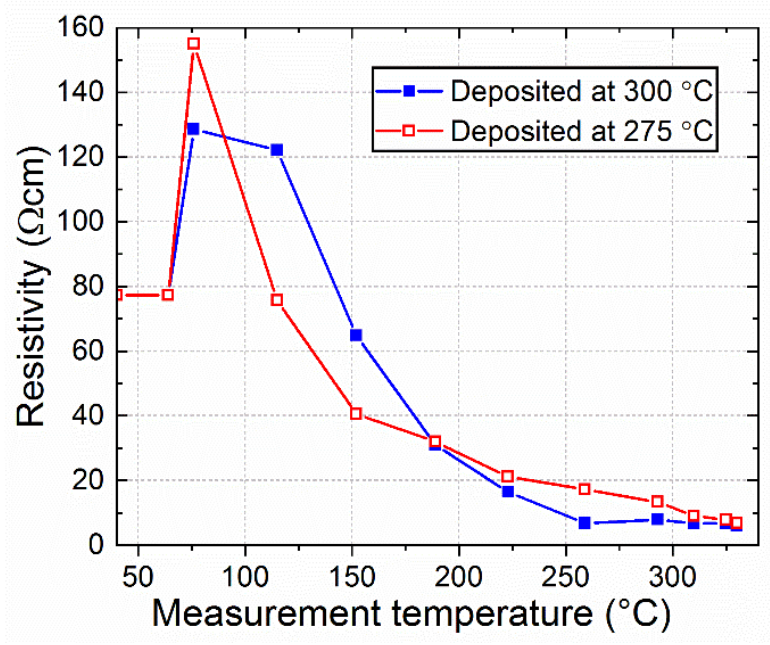

Figure 8. Resistivity versus temperature (in air) of $50 \mathrm{~nm}$ $\mathrm{MoO}_{\mathrm{x}}$ films deposited at 275 and $300{ }^{\circ} \mathrm{C}$ on $500 \mathrm{~nm} \mathrm{SiO} / \mathrm{Si}$ substrates.

Finally, a simple gas sensor device was constructed by depositing a $50 \mathrm{~nm} \mathrm{MoO}_{\mathrm{x}}$ film at $275{ }^{\circ} \mathrm{C}$ on a silicon substrate covered with $500 \mathrm{~nm}$ of $\mathrm{SiO}_{2}$. The device was contacted using two silver point contacts. The $275^{\circ} \mathrm{C}$ sample was chosen because of its phase composition: as described above, the films deposited at $275^{\circ} \mathrm{C}$ contained an unidentified molybdenum suboxide phase as the only crystalline phase and had surface and bulk stoichiometries of $\mathrm{MoO}_{2.4}$ and $\mathrm{MoO}_{2.8}$ according to synchrotron-based XPS and ToFERDA, respectively. Unlike $\mathrm{MoO}_{3},{ }^{25-30}$ molybdenum suboxides have not, to the best of our knowledge, been previously studied as hydrogen gas sensor materials.

The $\mathrm{MoO}_{\mathrm{x}}$ sensor exhibited a clear, reversible change in conductance when exposed to different concentrations of hydrogen gas. The response against $\mathrm{H}_{2}$ was quantified using the absolute value of sensitivity (S), which represents the change in conductance compared to that measured in dry air as defined in Eq. 1, where $C_{\mathrm{E}}$ and $\mathrm{C}_{\mathrm{B}}$ denote conductance during exposure to the target gas and baseline in dry air, respectively. Additionally, response (recovery) times were defined as the time passed until the sensor reached $90 \%$ (10\%) of the maximum signal for a given concentration. Furthermore, following a common convention, a decrease in conductance when exposed to hydrogen is designated as p-type response and an increase is termed n-type response. ${ }^{78}$

$$
\text { Sensitivity }(S)=\left[\left(\frac{\left|C_{E}-C_{B}\right|}{C_{B}}\right) \times 100\right] \quad \text { Equation } 1
$$

The $\mathrm{MoO}_{\mathrm{x}}$ sensor showed an overall p-type response to hydrogen when the sensor was operated at $120^{\circ} \mathrm{C}$. During each hydrogen pulse the sensor exhibited a weak initial ntype response, in other words an increase in conductance, but a much stronger p-type response, i.e. decrease in conductance quickly followed leading to an overall p-type response of the sensor. The semiconducting molybdenum 
oxides usually behave as n-type semiconductors and gas sensors. ${ }^{25-30}$ Although p-type response has also been reported for $\mathrm{MoO}_{3}$ gas sensors, ${ }^{32}$ reasons for the p-type behavior are not understood at present.

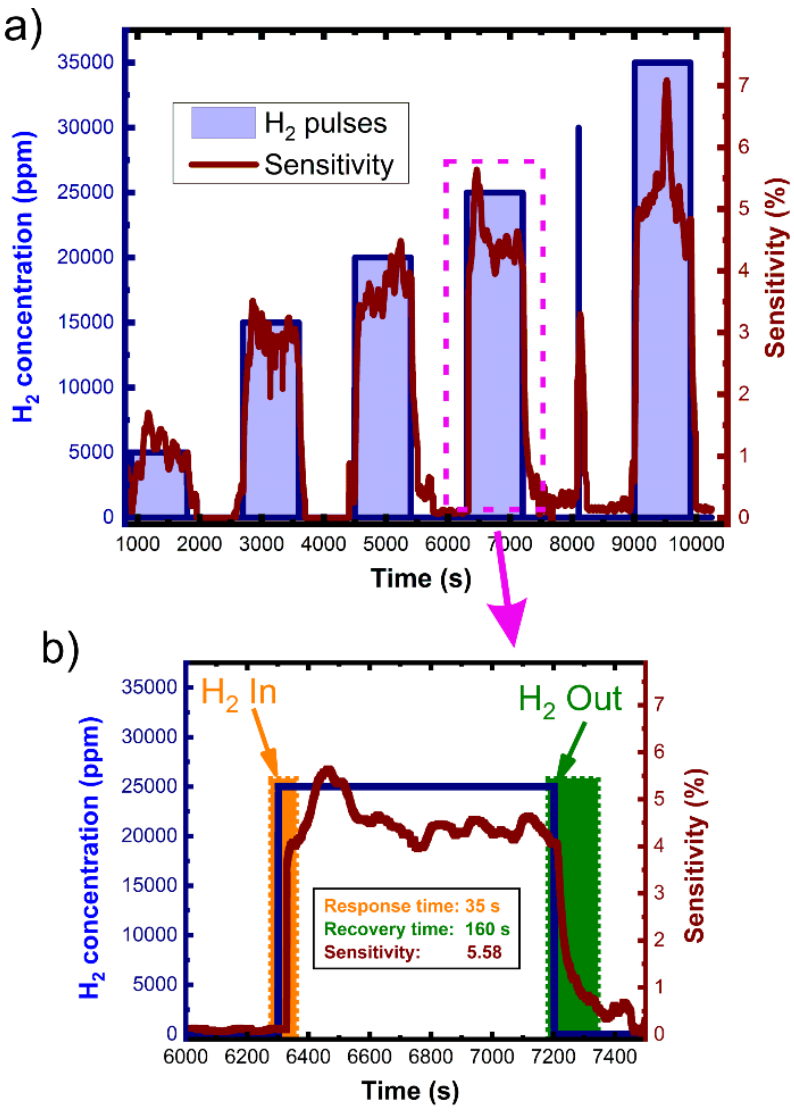

Figure 9. Dynamic sensor response of a $50 \mathrm{~nm} \mathrm{MoO}_{\mathrm{x}}$ film deposited at $275{ }^{\circ} \mathrm{C}$ : a) complete measurement against six different concentrations of $\mathrm{H}_{2}$ (5000-3500o ppm) and two different exposure times ( 1 and $15 \mathrm{~min}$ ) and b) a more detailed view of the $15 \mathrm{~min} 25000 \mathrm{ppm} \mathrm{H}_{2}$ pulse along with the extracted sensor performance. The measurements were done at $120^{\circ} \mathrm{C}$.

The sensitivity increased from 1.6 to $6.9 \%$ when the $\mathrm{H}_{2}$ concentration increased from 5000 to $35000 \mathrm{ppm}$ (Figure 9a). The sensor responded rapidly to the changes in the atmosphere with response and recovery times of 36 and $160 \mathrm{~s}$ determined during a 15 minute $25000 \mathrm{ppm}_{2}$ pulse (Figure 9b). Even a one-minute pulse of $\mathrm{H}_{2}$ resulted in a sensitivity of $3.2 \%$ at 30000 ppm $\mathrm{H}_{2}$ concentration. Thus, the sensor showed fast kinetics as well as a repeatable and reversible response with a capability to distinguish between different hydrogen concentrations at a relatively low operating temperature of only $120^{\circ} \mathrm{C}$. Future work is planned with more sophisticated interdigitated current collectors (IDEs) in order to obtain more detailed information on the sensing mechanisms as well as to use higher testing temperatures to increase the sensitivity.

\section{Conclusions}

We introduced bis(tert-butylimido)bis $\left(N, N^{\prime}\right.$ diisopropylacetamidinato) compounds of molybdenum and tungsten as precursors for atomic layer deposition.
$\mathrm{MoO}_{\mathrm{x}}$ and $\mathrm{WO}_{\mathrm{x}}(\mathrm{x} \approx 3)$ films were deposited using ozone as a reactant at 200 to $350{ }^{\circ} \mathrm{C}$. Both precursors yielded uniform films, although the growth behaviors differed: $\mathrm{MoO}_{x}$ films grew at a high growth rate of up to $2 \AA$ /cycle at 300 ${ }^{\circ} \mathrm{C}$ but without complete saturation, whereas the growth of $\mathrm{WO}_{\mathrm{x}}$ was saturative with a growth rate of $0.45 \AA /$ cycle at $300{ }^{\circ} \mathrm{C}$. Crystallinity and composition could be tuned by changing deposition conditions, especially the deposition temperature, but also film thickness and precursor pulse times. Whereas $\mathrm{WO}_{\mathrm{x}}$ crystallized to $\mathrm{WO}_{3}$ at $300{ }^{\circ} \mathrm{C}$ and above, $\mathrm{MoO}_{\mathrm{x}}$ formed crystalline suboxide $\left(275-300{ }^{\circ} \mathrm{C}\right.$ ) and $\alpha-\mathrm{MoO}_{3}\left(300-350{ }^{\circ} \mathrm{C}\right)$ phases. Crystalline films of both metal oxides were very pure and close to the expected stoichiometry. Synchrotron-based surface enhanced photoemission spectroscopy revealed a high amount of oxygen vacancies on the surface of a $\mathrm{MoO}_{\mathrm{x}}$ suboxide film deposited at $275^{\circ} \mathrm{C}$. The temperature-dependent resistivity of the $\mathrm{MoO}_{\mathrm{x}}$ films suggested the films to be suitable for gas sensor applications. A simple hydrogen gas sensor device constructed using a $50 \mathrm{~nm}$ suboxide $\mathrm{MoO}_{\mathrm{x}}$ film showed reversible and fast response to hydrogen gas at low temperature. The present results form a solid base for further indepth studies exploring the use of uniform and conformal molybdenum and tungsten oxide films with controlled crystallinity as gas sensors as well as in other applications, such as catalysis and energy storage.

\section{ASSOCIATED CONTENT}

Supporting Information. Thickness measurements using different methods (ellipsometry, EDS, and XRR), SEM images of $\mathrm{MoO}_{\mathrm{x}}$ film deposited in a trench structure. Further XRD and Raman data of $\mathrm{MoO}_{\mathrm{x}}$ and $\mathrm{WO}_{\mathrm{x}}$ films deposited at different temperatures and with different number of ALD cycles. AFM images of $\mathrm{MoO}_{x}$ films deposited at $300{ }^{\circ} \mathrm{C}$. SEM images, $\mathrm{X}$-ray diffractograms, and refractive indices of $\mathrm{MoO}_{\mathrm{x}}$ and $\mathrm{WO}_{\mathrm{x}}$ films deposited using different precursor pulse lengths. Photoelectron survey spectra, tabulated photoemission results, X-ray diffractograms and SEM images of a $50 \mathrm{~nm} \mathrm{MoO}_{\mathrm{x}}$ film deposited at $275{ }^{\circ} \mathrm{C}$. This material is available free of charge via the Internet at http://pubs.acs.org.

\section{AUTHOR INFORMATION}

\section{Corresponding Authors}

${ }^{*}$ M. Mattinen. E-mail: miika.mattinen@helsinki.fi

${ }^{*}$ M. Ritala. E-mail: mikko.ritala@helsinki.fi

\section{Author Contributions}

The manuscript was written through contributions of all authors.

\section{Notes}

The authors declare no competing financial interest.

\section{ACKNOWLEDGMENT}

The research was supported by ASM Microchemistry and the Finnish Centre of Excellence in Atomic Layer Deposition (ALDCoE) funded by the Academy of Finland. The authors from Ruhr-University Bochum and Heinrich Heine University Düsseldorf acknowledge the funding from European Funds for Regional Development (EFRE-0800672-FunALD). 
Alexander Sadlo, Martin Wilken and Annika Krusenbaum are acknowledged for synthesizing the precursors. We acknowledge the use of DELTA (Dortmund Electron Accelerator) for synchrotron based photoemission measurements. We also extend our sincere thanks to Ph.D. students Karim Shamout and Peter Roese and Prof. Dr. Carsten Westphal.

\section{REFERENCES}

(1) de Castro, I. A.; Datta, R. S.; Ou, J. Z.; CastellanosGomez, A.; Sriram, S.; Daeneke, T.; Kalantar-zadeh, K. Molybdenum Oxides - From Fundamentals to Functionality. Adv. Mater. 2017, 29, 1701619.

(2) Huang, Z.-F.; Song, J.; Pan, L.; Zhang, X.; Wang, L.; Zou, J.-J. Tungsten Oxides for Photocatalysis, Electrochemistry, and Phototherapy. Adv. Mater. 2015, 27, 5309-5327.

(3) Zheng, H.; Ou, J. Z.; Strano, M. S.; Kaner, R. B.; Mitchell, A.; Kalantar-zadeh, K. Nanostructured Tungsten Oxide - Properties, Synthesis, and Applications. Adv. Funct. Mater. 2011, 21, 2175-2196.

(4) Kihlborg, L. Studies on Molybdenum Oxides. Acta Chem. Scand. 1959, 13, 954-962.

(5) Kihlborg, L. The Crystal Chemistry of Molybdenum Oxides. In Advances in Chemistry: Nonstoichiometric Compounds; Ward, R., Ed.; American Chemical Society: Washington, D.C., 1963; Vol. 39, pp 37-45.

(6) Tilley, R. J. D. The Crystal Chemistry of the Higher Tungsten Oxides. Int. J. Refract. Met. Hard Mater. 1995, 13, 93109.

(7) Migas, D. B.; Shaposhnikov, V. L.; Borisenko, V. E. Tungsten Oxides. II. The Metallic Nature of Magnéli Phases. J. Appl. Phys. 2010, 108, 093714.

(8) Smith, R. L.; Rohrer, G. S. Scanning Probe Microscopy of Cleaved Molybdates: $\alpha-\mathrm{MoO}_{3}(\mathrm{o10}), \mathrm{Mo}_{18} \mathrm{O}_{52}(100), \mathrm{Mo}_{8} \mathrm{O}_{23}(\mathrm{o10})$, and $\eta-\mathrm{Mo}_{4} \mathrm{O}_{11}(100)$. J. Solid State Chem. 1996, 124, 104-115.

(9) da Luz, M. S.; de Campos, A.; White, B. D.; Neumeier, J. J. Electrical Resistivity, High-Resolution Thermal Expansion, and Heat Capacity Measurements of the Charge-Density Wave Compound $\gamma-\mathrm{Mo}_{4} \mathrm{O}_{11}$. Phys. Rev. B 20o9, 79, 233106.

(10) Rogers, D. B.; Shannon, R. D.; Sleight, A. W.; Gillson, J. L. Crystal Chemistry of Metal Dioxides with Rutile-Related Structures. Inorg. Chem. 1969, 8, 841-849.

(11) Kanu, S. S.; Binions, R. Thin Films for Solar Control Applications. Proc. R. Soc. A. 2009, 466, 19-44.

(12) Bettahar, M. M.; Costentin, G.; Savary, L.; Lavalley, J. C. On the Partial Oxidation of Propane and Propylene on Mixed Metal Oxide Catalysts. Appl. Catal. A 1996, 145, 1-48.

(13) Dong, P.; Hou, G.; Xi, X.; Shao, R.; Dong, F. WO-Based Photocatalysts: Morphology Control, Activity Enhancement and Multifunctional Applications. Environ. Sci. Nano 2017, 4, 539557.

(14) Szilágyi, I. M.; Fórizs, B.; Rosseler, O.; Szegedi, Á.; Németh, P.; Király, P.; Tárkányi, G.; Vajna, B.; Varga-Josepovits, K.; László, K. Tóth, A. L.; Baranyai, P.; Leskelä, M. $\mathrm{WO}_{3}$ Photocatalysts: Influence of Structure and Composition. J. Catal. 2012, 294, 119-127.

(15) Long, H.; Zeng, W.; Zhang, H. Synthesis of $\mathrm{WO}_{3}$ and Its Gas Sensing: A Review. J. Mater. Sci: Mater. Electron. 2015, 26, 4698-4707.

(16) Eranna, G.; Joshi, B. C.; Runthala, D. P.; Gupta, R. P. Oxide Materials for Development of Integrated Gas Sensors - A Comprehensive Review. Crit. Rev. Solid State Mater. Sci. 2004, 29, 111-188.

(17) Arita, M.; Kaji, H.; Fujii, T.; Takahashi, Y. Resistance Switching Properties of Molybdenum Oxide Films. Thin Solid Films 2012, 520, 4762-4767.
(18) Jeong, D. S.; Thomas, R.; Katiyar, R. S.; Scott, J. F.; Kohlstedt, H.; Petraru, A.; Hwang, C. S. Emerging Memories: Resistive Switching Mechanisms and Current Status. Rep. Prog. Phys. 2012, 75, 076502.

(19) Ji, Y.; Yang, Y.; Lee, S.-K.; Ruan, G.; Kim, T.-W.; Fei, H.; Lee, S.-H.; Kim, D.-Y.; Yoon, J.; Tour, J. M. Flexible Nanoporous $\mathrm{WO}_{3-\mathrm{x}}$ Nonvolatile Memory Device. ACS Nano 2016, 10, 75987603.

(20) Chernova, N. A.; Roppolo, M.; Dillon, A. C.; Whittingham, M. S. Layered Vanadium and Molybdenum Oxides: Batteries and Electrochromics. J. Mater. Chem. 2009, 19, 2526-2552.

(21) Song, J.; Huang, Z.-F.; Pan, L.; Zou, J.-J.; Zhang, X.; Wang, L. Oxygen-Deficient Tungsten Oxide as Versatile and Efficient Hydrogenation Catalyst. ACS Catal. 2015, 5, 6594-6599.

(22) Machiels, C. J.; Cheng, W. H.; Chowdhry, U.; Farneth, W. E.; Hong, F.; McCarron, E. M.; Sleight, A. W. The Effect of the Structure of Molybdenum Oxides on the Selective Oxidation of Methanol. Appl. Catal. 1986, 25, 249-256.

(23) Yao, D. D.; Ou, J. Z.; Latham, K.; Zhuiykov, S.; O'Mullane, A. P.; Kalantar-zadeh, K. Electrodeposited $\alpha$ - and $\beta$ Phase $\mathrm{MoO}_{3}$ Films and Investigation of Their Gasochromic Properties. Cryst. Growth Des. 2012, 12, 1865-1870.

(24) Delmon, B. Solid State Reactions in Catalysts: An Approach to Real Active Sytems and Their Deactivation. In Studies in Surface Science and Catalysis; Bartholomew, C. H., Fuentes, G. A., Eds.; Elsevier B.V.: Amsterdam, Netherlands, 1997; Vol. 111, pp 39-51.

(25) Alsaif, M. M. Y. A.; Balendhran, S.; Field, M. R.; Latham, K.; Wlodarski, W.; Ou, J. Z.; Kalantar-zadeh, K. Two Dimensional $\alpha-\mathrm{MoO}_{3}$ Nanoflakes Obtained Using SolventAssisted Grinding and Sonication Method: Application for $\mathrm{H}_{2}$ Gas Sensing. Sens. Actuators B. 2014, 192, 196-204.

(26) Rahmani, M. B.; Keshmiri, S. H.; Yu, J.; Sadek, A. Z.; AlMashat, L.; Moafi, A.; Latham, K.; Li, Y. X.; Wlodarski, W.; Kalantar-zadeh, K. Gas Sensing Properties of Thermally Evaporated Lamellar $\mathrm{MoO}_{3}$. Sens. Actuators B 2010, 145, 13-19.

(27) Yang, S.; Wang, Z.; Hu, Y.; Luo, X.; Lei, J.; Zhou, D.; Fei, L.; Wang, Y.; Gu, H. Highly Responsive Room-Temperature Hydrogen Sensing of $\alpha-\mathrm{MoO}_{3}$ Nanoribbon Membranes. ACS Appl. Mater. Interfaces 2015, 7, 9247-9253.

(28) Luo, X.; You, K.; Hu, Y.; Yang, S.; Pan, X.; Wang, Z.; Chen, W.; Gu, H. Rapid Hydrogen Sensing Response and Aging of $\alpha-\mathrm{MoO}_{3}$ Nanowires Paper Sensor. Int. J. Hydrogen Energy 2017, 42, 8399-8405.

(29) Illyaskutty, N.; Kohler, H.; Trautmann, T.; Schwotzer, M.; Mahadevan Pillai, V. P. Hydrogen and Ethanol Sensing Properties of Molybdenum Oxide Nanorods Based Thin Films: Effect of Electrode Metallization and Humid Ambience. Sens. Actuators B 2013, 187, 611-621.

(30) Sunu, S. S.; Prabhu, E.; Jayaraman, V.; Gnanasekar, K. I.; Seshagiri, T. K.; Gnanasekaran, T. Electrical Conductivity and Gas Sensing Properties of $\mathrm{MoO}_{3}$. Sens. Actuators B 2004, 101, 161174 .

(31) Galatsis, K.; Li, Y. X.; Wlodarski, W.; Comini, E.; Sberveglieri, G.; Cantalini, C.; Santucci, S.; Passacantando, M. Comparison of Single and Binary Oxide $\mathrm{MoO}_{3}, \mathrm{TiO}_{2}$ and $\mathrm{WO}_{3}$ Sol-Gel Gas Sensors. Sens. Actuators B 2002, 83, 276-28o.

(32) Çiftyürek, E.; Sabolsky, K.; Sabolsky, E. M. Molybdenum and Tungsten Oxide Based Gas Sensors for High Temperature Detection of Environmentally Hazardous Sulfur Species. Sens. Actuators B 2016, 237, 262-274.

(33) Wildfire, C.; Çiftyürek, E.; Sabolsky, K.; Sabolsky, E. M. Fabrication and Testing of High-Temperature Nano-Derived Resistive-Type Microsensors for Hydrogen Sensing. J. Electrochem. Soc. 2014, 161, B3094-3102. 
(34) Ritala, M.; Niinistö, J. Atomic Layer Deposition. In Chemical Vapor Deposition: Precursors, Processes and Applications; Jones, A. C., Hitchman, M. L., Eds.; Royal Society of Chemistry: Cambridge, 2009; pp 158-206.

(35) George, S. M. Atomic Layer Deposition: An Overview. Chem. Rev. 2010, 110, 111-131.

(36) Ritala, M.; Leskelä, M. Atomic Layer Deposition. In Handbook of Thin Film Materials; Nalwa, H. S., Ed.; Academic: San Diego, 2002; Vol. 1, pp 103-159.

(37) Diskus, M.; Nilsen, O.; Fjellvåg, H. Growth of Thin Films of Molybdenum Oxide by Atomic Layer Deposition. J. Mater. Chem. 2011, 21, 705.

(38) Malm, J.; Sajavaara, T.; Karppinen, M. Atomic Layer Deposition of $\mathrm{WO}_{3}$ Thin Films Using $\mathrm{W}(\mathrm{CO})_{6}$ and $\mathrm{O}_{3}$ Precursors. Chem. Vap. Depos. 2012, 18, 245-248.

(39) Song, J.-G.; Ryu, G. H.; Lee, S. J.; Sim, S.; Lee, C. W.; Choi, T.; Jung, H.; Kim, Y.; Lee, Z.; Myoung, J.-M.; Dusarrat, C.; Lansalot-Matras, C.; Park, J.; Choi, H.; Kim, H. Controllable Synthesis of Molybdenum Tungsten Disulfide Alloy for Vertically Composition-Controlled Multilayer. Nat. Commun. 2015, 6, 7817.

(40) Vos, M. F. J.; Macco, B.; Thissen, N. F. W.; Bol, A. A.; Kessels, W. M. M. Atomic Layer Deposition of Molybdenum Oxide from $\left(\mathrm{N}^{\mathrm{t} B u}\right)_{2}\left(\mathrm{NMe}_{2}\right)_{2} \mathrm{Mo}$ and $\mathrm{O}_{2}$ Plasma. J. Vac. Sci. Technol. A 2016, 34, o1A103.

(41) Bertuch, A.; Sundaram, G.; Saly, M.; Moser, D.; Kanjolia, R. Atomic Layer Deposition of Molybdenum Oxide Using Bis(tert-Butylimido)bis(dimethylamido) Molybdenum. J. Vac. Sci. Technol. A 2014, 32, o1A119.

(42) Balasubramanyam, S.; Sharma, A.; Vandalon, V. Knoops, H. C. M.; Kessels, W. M. M.; Bol, A. A. Plasma-Enhanced Atomic Layer Deposition of Tungsten Oxide Thin Films Using $\left({ }^{(} \mathrm{BuN}\right)_{2}\left(\mathrm{Me}_{2} \mathrm{~N}\right)_{2} \mathrm{~W}$ and $\mathrm{O}_{2}$ Plasma. J. Vac. Sci. Technol. A 2018, 36, o1B103.

(43) Bergum, K.; Magrasó, A.; Fjellvåg, H.; Nilsen, O. Thin Film Fabrication and Characterization of Proton Conducting Lanthanum Tungstate. J. Mater. Chem. A 2014, 2, 18463-18471.

(44) Mouat, A. R.; Mane, A. U.; Elam, J. W.; Delferro, M.; Marks, T. J.; Stair, P. C. Volatile Hexavalent Oxo-Amidinate Complexes: Molybdenum and Tungsten Precursors for Atomic Layer Deposition. Chem. Mater. 2016, 28, 1907-1919.

(45) Jurca, T.; Peters, A. W.; Mouat, A. R.; Farha, O. K.; Hupp, J. T.; Lohr, T. L.; Delferro, M.; Marks, T. J. SecondGeneration Hexavalent Molybdenum Oxo-Amidinate Precursors for Atomic Layer Deposition. Dalt. Trans. 2017, 46, 1172-1178.

(46) Nanayakkara, C. E.; Vega, A.; Liu, G.; Dezelah, C. L.; Kanjolia, R. K.; Chabal, Y. J. Role of Initial Precursor Chemisorption on Incubation Delay for Molybdenum Oxide Atomic Layer Deposition. Chem. Mater. 2016, 28, 8591-8597.

(47) Drake, T. L.; Stair, P. C. Vapor Deposition of Molybdenum Oxide Using Bis(ethylbenzene) Molybdenum and Water. J. Vac. Sci. Technol. A 2016, 34, 051403.

(48) Mattinen, M.; King, P. J.; Khriachtchev, L.; Heikkilä, M. J.; Fleming, B.; Rushworth, S.; Mizohata, K.; Meinander, K.; Räisänen, J.; Ritala, M.; Leskelä, M. Atomic Layer Deposition of Crystalline Molybdenum Oxide Thin Films and Phase Control by Post-Deposition Annealing. Mater. Today Chem. 2018, 9, 17-27.

(49) Moody, M. J.; Henning, A.; Jurca, T.; Shang, J. Y.; Bergeron, H.; Balla, I.; Olding, J. N.; Weiss, E. A.; Hersam, M. C.; Lohr, T. L.; Marks, T. J.; Lauhon, L. J. Atomic Layer Deposition of Molybdenum Oxides with Tunable Stoichiometry Enables Controllable Doping of $\mathrm{MoS}_{2}$. Chem. Mater. 2018, 30, 3628-3632.

(50) Song, J.-G..; Park, J.; Lee, W.; Choi, T.; Jung, H.; Lee, C. W.; Hwang, S.-H; Myoung, J. M.; Jung, J.-H.; Kim, S.-H.; Lansalot-Matras, C.; Kim, H. Layer-Controlled, Wafer-Scale and Conformal Synthesis of Tungsten Disulfide Nanosheets Using Atomic Layer Deposition. ACS Nano 2013, 7, 11333-11340.
(51) Tägtström, P.; Mårtensson, P.; Jansson, U.; Carlsson, J.O. Atomic Layer Epitaxy of Tungsten Oxide Films Using Oxyfluorides as Metal Precursors. J. Electrochem. Soc. 1999, 146, 3139-3143.

(52) Dezelah, C. L.; El-Kadri, O. M.; Szilágyi, I. M.; Campbell, J. M.; Arstila, K.; Niinistö, L.; Winter, C. H. Atomic Layer Deposition of Tungsten(III) Oxide Thin Films from $\mathrm{W}_{2}\left(\mathrm{NMe}_{2}\right)_{6}$ and Water: Precursor-Based Control of Oxidation State in the Thin Film Material. J. Am. Chem. Soc. 20o6, 128, 9638-9639.

(53) Strobel, A.; Schnabel, H.-D.; Reinhold, U.; Rauer, S.; Neidhardt, A. Room Temperature Plasma Enhanced Atomic Layer Deposition for $\mathrm{TiO}_{2}$ and $\mathrm{WO}_{3}$ Films. J. Vac. Sci. Technol. A 2016, 34, o1A118.

(54) Cwik, S.; Milanov, A. P.; Gwildies, V.; Thiede, T. B.; Vidyarthi, V. S.; Savan, A.; Meyer, R.; Becker, H.-W.; Rogalla, D.; Ludwig, A.; Fischer, R. A.; Devi, A. Engineered Tungsten OxyNitride Thin Film Materials for Photocatalytical Water Splitting Fabricated by MOCVD. ECS Trans. 2010, 28 (8), 159-165.

(55) de los Arcos, T.; Cwik, S.; Milanov, A. P.; Gwildies, V.; Parala, H.; Wagner, T.; Birkner, A.; Rogalla, D.; Becker, H.-W.; Winter, J.; Ludwig, A.; Fischer, R. A.; Devi, A. Influence of Process Parameters on the Crystallinity, Morphology and Composition of Tungsten Oxide-Based Thin Films Grown by Metalorganic Chemical Vapor Deposition. Thin Solid Films 2012, 522, 11-16.

(56) Srinivasan, N. B.; Thiede, T. B.; de los Arcos, T.; Gwildies, V.; Krasnopolski, M.; Becker, H.-W.; Rogalla, D.; Devi, A.; Fischer, R. A. Transition Metal Nitride Thin Films Grown by MOCVD Using Amidinato Based Complexes $\left[\mathrm{M}\left(\mathrm{N}^{\mathrm{t} B u}\right)_{2}\left\{\left({ }^{\mathrm{P} r N}\right)_{2} \mathrm{CMe}\right\}_{2}\right](\mathrm{M}=\mathrm{Mo}, \mathrm{W})$ as Precursors. Surf. Coat. Technol. 2013, 230, 130-136.

(57) Cwik, S.; Mitoraj, D.; Reyes, O. M.; Rogalla, D.; Peeters, D.; Kim, J.; Schütz, H. M.; Bock, C.; Beranek, R.; Devi, A. Direct Growth of $\mathrm{MoS}_{2}$ and $\mathrm{WS}_{2}$ Layers by Metal Organic Chemical Vapor Deposition. Adv. Mater. Interfaces 2018, 5, 1800140.

(58) Suntola, T. Atomic Layer Epitaxy. Thin Solid Films 1992, 216, 84-89.

(59) Gwildies, V.; Thiede, T. B.; Amirjalayer, S.; Alsamman, L.; Devi, A.; Fischer, R. A. All-Nitrogen Coordinated Amidinato/imido Complexes of Molybdenum and Tungsten: Syntheses and Characterization. Inorg. Chem. 2o10, 49, 84878494.

(6o) Waldo, R. A. An Iteration Procedure to Calculate Film Compositions and Thicknesses in Electron-Probe Microanalysis. In Microbeam Analysis; Newbury, D. E., Ed.; San Francisco Press: San Francisco, 1988; pp 310-314.

(61) CRC Handbook of Chemistry and Physics, 98th ed. [Online]; CRC Press: Boca Raton, FL, 2017-2018; http://hbcpnetbase.com (accessed May 3, 2018)

(62) Niskanen, A.; Hatanpää, T.; Ritala, M.; Leskelä, M. Thermogravimetric Study of Volatile Precursors for Chemical Thin Film Deposition. Estimation of Vapor Pressures and Source Temperatures. J. Therm. Anal. Calorim. 2001, 64, 955-964.

(63) Puurunen, R. L. Surface Chemistry of Atomic Layer Deposition: A Case Study for the Trimethylaluminum/Water Process. J. Appl. Phys. 2005, 97, 121301.

(64) Szekeres, A.; Ivanova, T.; Gesheva, K. Spectroscopic Ellipsometry Study of CVD Molybdenum Oxide Films: Effect of Temperature. J. Solid State Electrochem. 2002, 7, 17-20.

(65) Deb, S. K. Physical Properties of a Transition Metal Oxide: Optical and Photoelectric Properties of Single Crystal and Thin Film Molybdenum Trioxide. Proc. R. Soc. London Ser. A 1968, 304, 211-231.

(66) Bilousov, O. V.; Ren, Y.; Törndahl, T.; Donzel-Gargand, O.; Ericson, T.; Platzer-Björkman, C.; Edoff, M.; Hägglund, C. 
Atomic Layer Deposition of Cubic and Orthorhombic Phase Tin Monosulfide. Chem. Mater. 2017, 29, 2969-2978.

(67) Heil, S. B. S.; Langereis, E.; Roozeboom, F.; van de Sanden, M. C. M.; Kessels, W. M. M. Low-Temperature Deposition of TiN by Plasma-Assisted Atomic Layer Deposition. J. Electrochem. Soc. 2006, 153, G956-965.

(68) Howard, C. J.; Luca, V.; Knight, K. S. HighTemperature Phase Transitions in Tungsten Trioxide - the Last Word? J. Phys.: Condens. Matter 2002, 14, 377-387.

(69) Nishide, T.; Mizukami, F. Control of Refractive Index of Sol-Gel Tungsten Oxide Films. J. Sol-Gel Sci. Technol. 1996, 6, 263-267.

(70) Sawada, S.; Danielson, G. C. Optical Indices of Refraction of $\mathrm{WO}_{3}$. Phys. Rev. 1959, 113, 1008-1013.

(71) Quincy, R. B.; Houalla, M.; Proctor, A.; Hercules, D. M. Distribution of Molybdenum Oxidation States in Reduced $\mathrm{Mo} / \mathrm{TiO}_{2}$ Catalysts: Correlation with Benzene Hydrogenation Activity. J. Phys. Chem. 1990, 94, 1520-1526.

(72) Baltrusaitis, J.; Mendoza-Sanchez, B.; Fernandez, V.; Veenstra, R.; Dukstiene, N.; Roberts, A.; Fairley, N. Generalized Molybdenum Oxide Surface Chemical State XPS Determination via Informed Amorphous Sample Model. Appl. Surf. Sci. 2015, 326, 151-161.

(73) Irfan; Ding, H.; Gao, Y.; Small, C.; Kim, D. Y.; Subbiah, J.; So, F. Energy Level Evolution of Air and Oxygen Exposed Molybdenum Trioxide Films. Appl. Phys. Lett. 2010, 96, 243307.

(74) Vasilopoulou, M.; Douvas, A. M.; Georgiadou, D. G.; Palilis, L. C.; Kennou, S.; Sygellou, L.; Soultati, A.; Kostis, I.; Papadimitropoulos, G.; Davazoglou, D.; Argitis, P. The Influence of Hydrogenation and Oxygen Vacancies on Molybdenum Oxides Work Function and Gap States for Application in Organic Optoelectronics. J. Am. Chem. Soc. 2012, 134, 1617816187.

(75) Greiner, M. T.; Chai, L.; Helander, M. G.; Tang, W.-M.; Lu, Z.-H. Transition Metal Oxide Work Functions: The Influence of Cation Oxidation State and Oxygen Vacancies. Adv. Funct. Mater. 2012, 22, 4557-4568.

(76) Miyata, N.; Akiyoshi, S. Preparation and Electrochromic Properties of RF-Sputtered Molybdenum Oxide Films. J. Appl. Phys. 1985, 58, 1651-1655.

(77) Carcia, P. F.; McCarron, E. M. Synthesis and Properties of Thin Film Polymorphs of Molybdenum Trioxide. Thin Solid Films 1987, 155, 53-63.

(78) Sabolsky, E. M.; Çiftyürek, E.; Wildire, C.; Sabolsky, K.; Taub, J.; Sierros, K.; Evans, T. H. Nano-Derived Microsensors for Monitoring Gas Species in Harsh-Environments. ECS Trans. 2014, 61, 375-385. 
Table of Contents Graphic

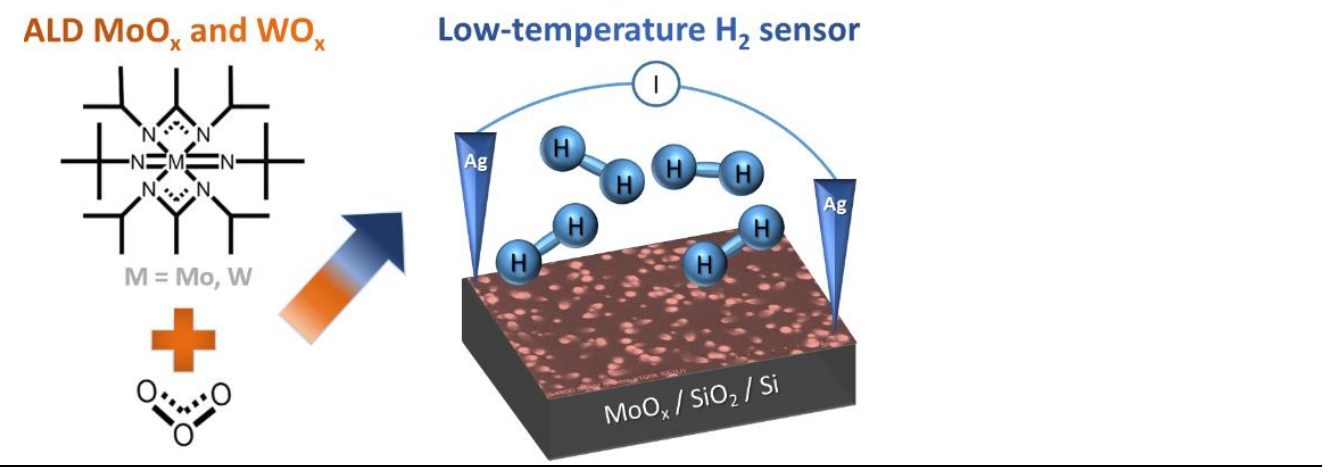

